\title{
SATICININ ZAPTTAN SORUMLULUĞUNUN MADDİ KOŞULLARI
}

DOI: https://doi.org/10.33717/deuhfd.704807

\section{Dr. Barış DEMIRSATAN*}

\section{$\ddot{O} \mathbf{z}$}

Bu çalışmada, satış sözleşmesinde zapttan sorumluluğun maddi koşulları incelenmiştir. Satıcının zapttan sorumluluğu, Roma hukukunun kalıntısıdır. Buna göre satıcı, tasarruf yetkisinin bulunmaması nedeniyle, alıcıya satılanı teslim etmesine rağmen, mülkiyeti devredemediği ve üçüncü kişi üstün hakkına dayanarak satılanı alıcının elinden aldığı takdirde zapt gerçekleşir. Dolayısıyla zaptın koşulları, geçerli bir satış sözleşmesi, satılanın teslim edilmiş olması, sözleşme kurulduğu anda üstün hakkın var olması ve satılanın alıcının elinden alınması olarak ifade edebilir. Bunun yanı sıra, zapttan sorumluluğa ilişkin zamanaşımının dolmaması, zapttan sorumluluğunun kaldırllmamış olması ve alıcının zapt tehlikesini bilmiyor olması lazım gelir. Her bir unsurun özellikleri, uygulama ve ögretideki görüşler çerçevesinde değerlendirilmiştir. Öte yandan bu sorumluluğun niteliği ve hukuki ayıptan farklılıklarına da değinilmiştir.

\section{Anahtar Kelimeler}

Satış sözleşmesi, Satıcının sorumluluğu, Zapt, Zaptın koşulları, Zapttan sorumluluk

\section{MATERIAL CONDITIONS FOR THE VENDOR'S LIABILITY FOR EVICTION (WARRANTY OF TITLE)}

\begin{abstract}
In this paper, the material conditions of liability for eviction in the sales contract have been examined. The vendor's liability for eviction is the remnant of Roman law. If the vendor, since he/she does not have the authority to

İstanbul Üniversitesi Hukuk Fakültesi, Medeni Hukuk Anabilim Dalı Araştırma Görevlisi (e-posta: baris.demirsatan@istanbul.edu.tr) ORCID: https://orcid.org/00000002-0228-5236 (Makalenin Geliş Tarihi: 05.02.2020) (Makale Gönderilme Tarihi: 06.02.2020/Makale Kabul Tarihi: 05.03.2020)
\end{abstract}


alienate, despite delivering the sold to the buyer, cannot transfer the ownership and on the basis of the superior right a third party reclaims subject matter of the sale, the eviction occurs. Therefore, the conditions of liability for eviction can be expressed as a valid sales contract, the delivery of the subject matter, the existence of superior rights at the time the contract was concluded and the withdrawal of the subject matter from the buyer. Furthermore, the statute of limitations should not have been expired and the liability for eviction should not been abolished or the buyer should not have been aware of the danger of eviction. The characteristics of each element are evaluated within the framework of the views in practice and legal doctrine. On the other hand, the nature of such liability and its differences from the legal defect are also mentioned.

\section{Keywords}

Sales agreement, Liability of vendor, Eviction, Conditions of eviction, Liability for warranty of title 


\section{GİRIŞ}

Yargı uygulamasında zapttan sorumluluk geniş bir yer almasa da tarihi ve kuramsal temelleri bakımından satış sözleşmesinde önemli bir işleve sahiptir. Bu çalışmada, satıcının zapttan sorumluluğunun koşulları incelenecektir. Bunun için öncelikle zapttan doğan sorumluluğun hukuki niteliği değerlendirilecektir. Ayrıca, zapttan sorumluluğun maddi hukuka ilişkin koşullarından önce, sorumluluğa ilişkin genel niteliği ile zamanaşımı konusuna değinilecektir. Çalışma, zapttan sorumluğa ilişkin Türk Borçlar Kanununda alıcıya yüklenmiş külfetleri ve alıcı lehine tanınmış ispat kolaylıklarını kapsamamakta olup zapttan sorumluluğun maddi koşullarıyla sınırlanmiştır.

\section{GENEL OLARAK SATICININ ZAPTTAN SORUMLULUĞU}

\subsection{Türk Borçlar Kanununda Zapt Kavramı}

Zapttan sorumluluk Türk Borçlar Kanununda özel bir sorumluluk rejimi olarak satış sözleşmesi kapsamında m. 214 vd. hükümlerinde düzenlenmektedir. Ancak zapt, satış sözleşmesine özgü bir terim değildir. Satış sözleşmesi dışında Türk Borçlar Kanunu "zapttan sorumluluk" kenar başlığ1 altında m. 309 ile kira sözleşmesinde özel olarak hüküm altına alınmıştır. Ayrıca, zapttan sorumluluğa satış sözleşmesindeki hükümlerin örneksemeyle uygulanmasını sağlamak üzere mal değişim (trampa) sözleşmesi (TBK m. 284) ve adi ortaklık sözleşmesinde katılma payı borcuna ilişkin olarak yer verilmiştir (TBK m. 621/III). Zapttan sorumluluk hakkında kavramsal bir çerçeve çizilmesi satış ve kira sözleşmelerindeki hükümler 1şığında mümkün olabilir.

TBK m. 214/I: "Satış sözleşmesinin kurulduğu sırada var olan bir hak dolayısıyla, satılanın tamamı veya bir kısmı bir üçüncü kişi tarafindan alıcının elinden alınırsa satıcı, bundan dolayı alıcıya karşı sorumlu olur.", TBK m. 309: "Bir üçüncü kişinin kiralananda kiracının hakkıyla bağdaşmayan bir hak ileri sürmesi durumunda kiraya veren, kiracının bildirimi üzerine davayı üstlenmek ve kiracının uğradı̆̆ her türlü zararı gidermekle yükümlüdür." şeklindedir. Buna göre zapt sözleşme konusu üzerinde sözleşmenin kurulduğu anda ${ }^{1}$ mevcut üstün bir hak nedeniyle üçüncü kişi tarafından sözleşme konusunun, onu temlik almak veya yararlanmak üzere teslim alan

Kira sözleşmesinde bu husus TBK m. 310 hükmünün kenar başlığından açıkça anlaşı1maktadır. 
kişinin elinden alınması olarak ifade edilebilir². Bu itibarla zapt, sözlük anlamı itibarıyla "tutma ", "hâkim olma", "ele geçirme" sözcüklerini ifade etmekteyken ${ }^{3}$ hukuki açıdan üstün hakka dayalı bir eylemi karşılamaktadır".

Zaptın gerçekleşmesi sözleşme konusunu oluşturan edimin yerine getirilmediği gösterir. Bu durumda, zapta maruz kalan sözleşme tarafı, karş1 tarafın sorumluluğuna genel hükümler uyarınca gidebilir. Bununla birlikte zapt olgusunun doğurduğu hukuki sonuçlar yukarıda belirtilen sözleşme tiplerinde özel olarak düzenlendiğinden her bir sözleşme tipi için bu özel sorumluluk rejimine ve genel hükümlere başvuru olanağı ayrıca değerlendirilmek gerekmektedir. Eş söyleyişle, zapt borca aykırılık oluşturur, birtakım sözleşmelerde bu borca aykırılık özel olarak düzenlenmiştir. Satış sözleşmesi de zapttan sorumluluğun en geniş ölçüde hüküm altına alındığı sözleşme tipini oluşturmaktadır ${ }^{5}$.

\subsection{Zapttan Sorumluluğunun Niteliği}

Satış sözleşmesi uyarınca satıcı, alıcıya satılanın mülkiyeti devretmek ve bu bağlamda zilyetliğini de devretmek borcu altındadır (TBK m. 210). Satılan, alıcıya teslim edildikten sonra üçüncü kişi tarafından; en geç satış sözleşmesinin kurulduğu anda var olan bir üstün hakka dayanılarak alıcının elinde alınırsa, bu durum satıcının mülkiyeti devir borcunu ifa etmediğini

2 Yavuz, Cevdet: Türk Borçlar Hukuku Özel Hükümler, İstanbul, 2014 (Hazırlayanlar: Yavuz, Cevdet/Acar, Faruk/Özen, Burak), s. 109, kira sözleşmesinde s. 426 ve dn. 131; Zevkliler, Aydın/Gökyayla, K. Emre: Borçlar Hukuku Özel Borç İlişkileri, Ankara, 2018, s. 141, kira sözleşmesinde s. 271; Gümüş, Mustafa Alper: Borçlar Hukuku Özel Hükümler, C. I, İstanbul, 2013, s. 53, kira sözleşmesinde s. 273; Aydoğdu, Murat/ Kahveci, Nalan: Türk Borçlar Hukuku Özel Borç İlişkileri, Ankara, 2019, s. 118, kira sözleşmesinde s. 397; Aral, Fahrettin/Ayrancı, Hasan: Borçlar Hukuku Özel Borç İlişkileri, Ankara, 2018, s. 107, kira sözleşmesinde s. 285-286; Atamer, Yeşim, "Taşınır Satımı Sözleşmesi”, Türk Borçlar Kanunu Sempozyumu, İstanbul, 2012, s. 218; Çabri, Sezer: "Taşınmaz Satışında Satıcının Zapttan Sorumluluğu", Marmara Üniversitesi Hukuk Fakültesi Hukuk Araştırmaları Dergisi, C. 22 S. 3 (2016-Prof. Dr. Cevdet Yavuz'a Armağan), s. 585-586; Doğu, H. Mert: “Ardı Ardına Teslimli Satış Sözleşmesinde Satıcının Ayıptan ve Zapttan Sorumluluğu”, Selçuk Üniversitesi Hukuk Fakültesi Dergisi, C. 26 S. 2 (2018), s. 520.

3 Kubbealtı Lugatı - Misalli Büyük Türkçe Sözlük (www.lugatim.com)

$4 \quad$ Aydoğdu/Kahveci, s. 119.

5 Nitekim bu sebeple kira sözleşmesindeki zapttan sorumluluğa satış sözleşmesinde hükümlerin örneksemeyle uygulanabileceği öğretide savunulmuştur: Zevkliler/ Gökyayla, s. 271; Hatemi, Hüseyin/Serozan, Rona/Arpacı, Abdülkadir: Borçlar Hukuku Özel Bölüm, İstanbul, 1992, s. 167; Yavuz, s. 430; Tandoğan, Haluk: Borçlar Hukuku Özel Borç İlişkileri, Cilt 1/2, İstanbul, 2008, s. 124-126. 
gösterir. $\mathrm{Bu}$ çerçevede satılanın alıcının elinden alınması halinde doğacak sorumluluk özel olarak ${ }^{6}$ Türk Borçlar Kanununda m. 214 ilâ 218 hükümleri

6 Zapt hükümleri ile genel borca aykırılık ve irade bozukluğu düzenlemelerinin yarışabileceği hususunda bkz. Eren, Fikret: Borçlar Hukuku Özel Hükümler, Ankara, 2019, N. 295 vd.; Gümüş, s. 54; Aral/Ayrancı, s. 107; Yavuz, s. 110 dn. 5; Hatemi/Serozan/ Arpacı, s. 80; Nomer, Haluk N./Engin, B. İlkay: Türk Borçlar Kanunu Şerhi Özel Borç İlişkileri Cilt I: Satış Sözleşmesi, Ankara, 2018, TBK m. 214, N. 25 vd.; Rüegg, Eric: "§ 5 Die Haftung des Grundstückverkäufers / I.-IV.”, Der Grundstückkauf, Ed. Alfred Koller, Bern, 2017, §5 N. 33; CHK-Handkommentar zum Schweizer PrivatrechtHrubesch-Millauer, Stephanie: Vertragsverhältnisse Teil 1: Innominatkontrakte, Kauf, Tausch, Schenkung, Miete, Leihe Art. 184 - 318 OR, Art. 192 OR, Zürih-BaselCenevre, 2016, Art. 192 OR, N. 7-8; Giger, Hans: Berner Kommentar Das Obligationen Recht 2. Abteilgung I. Teil Band 1. Abschnitt, Bern, 1980, Art. 192, N. 9 (kötü ifa), 10 (borçlu temerrüdü, yarışmanın her zaman mümkün olmadığı, satıcının ifa etmesinin beklemenin boşuna olduğu hallerde imkânsızlı̆̆ın doğacağı şeklinde) ve 11 (irade bozuklukları). Sadece irade bozukluklarında yarışma olabileceği görüşünde: Honsell, Heinrich: Basler Kommentar - Obligationenrecht I Art. 1-529 OR, 4. Bask1, 2007, Basel, Vorbem Art. 192-210 OR, N. 6-8; Venturi, Silvio/Zen-Ruffinen, Marie-Noëlle: Commentaire Romand-Code des Obligations Art. 1-529, Basel, 2012, Intro. Art. 192196a CO, N. 9-11; Tunçomağ, Kenan: Türk Borçlar Hukuku, 2. Cilt Özel Borç İlişkileri, İstanbul, 1977, s. 209; Tandoğan, Haluk: Borçlar Hukuku Özel Borç İlişkileri, Cilt 1/I, İstanbul, 2008, s. 148, Yazar genel hükümlere zaptın koşulları gerçekleşmediği ölçüde başvurulabileceğini kabul etmektedir.- JdT 1984 I 139: "Ayıplı bir mal teslim edildiğinde alıcının IBBK $\mathrm{m} .197 \mathrm{vd}$. uyarınca garanti sorumluluğuna gitmek ile IBBK $\mathrm{m}$. 23 uyarınca irade bozukluğu ile sakatlanmış sözleşmeyi hükümden düşürmek arasında seçim hakkının bulunduğu istikrar kazanmış içtihattır. Bu görüş, IBK m. 192 (Oser) Schönenberger $n .1$ ve Giger $n$. 11 İBK $m$. 192) anlamında hukuki kötü ifanın yapıldığ hallerde de geçerli olur.. .. Özellikle, alıcının irade bozukluğuna karşın sadece garanti sorumluluğuna dayanabilecek olması kabul edildiğinde, alıcı gerçek malikin satılanın zapt edilmesini beklemek zorunda kalacă̆l ve bu bekleyişe bağll olumsuzluklara belirsiz bir süre boyunca katlanmak zorunda kalkması bu görüşün gerekliliğini ortaya koyar." Borçlu temerrüdü veya irade bozukluğundan doğan haklar kullanıldıktan sonra zapt hükümlerine başvurulması mümkün değildir. Yarışma, bu andan önceki hukuki durum için geçerlidir. Öte yandan tam zaptın gerçekleşmesiyle sözleşme kendiliğinden sona erdiği için borçlu temerrüdü veya borçlunun sorumlu olduğu imkânsızlık nedeniyle tazminat istemine başvurmak olanaksız hale gelir. Kanun koyucunun böyle bir sınırlayıcı amaç taşımadığ 1 şeklinde aksi yönde: ZK-Zürcher Kommentar Band/Nr. V/2a Kommentar zum Schweizerischen Zivilgesetzbuch, Obligationenrecht, Kommentar zur 1. und 2. Abteilung (Art. 1-529 OR) Kauf und Schenkung, Zweite Lieferung, Art. 192204 OR, Schönle, Herbert/Higi, Peter: Zürih, 2005, Art. 192 OR, N. 12, Ayrıca bkz. N. 11, Yazarlar tam zapt halinde, ifa yerine olumlu zararı talep hakkının temerrüt hükümleri uyarınca saklı olduğunu, sözleşmeyi sonlandırmanın ise zapt hükümlerine bağlı olduğunu ifade etmektedir. Sözleşme iptal edilmediği sürece zapt ve hilenin yarışacağı: Ercoşkun Şenol, H. Kübra: "Türk Borçlar Hukukunda Hilenin Münferit Uygulama Alanları", Gazi Üniversitesi Hukuk Fakültesi Dergisi, C. 17 S. 4 (Ekim 2013), s. 90. Yarışmayı kabul etmeyen görüş: Koller, Alfred: Schweizerisches Obligationenrecht, 
arasında düzenlenmiştir. Böylece görülmektedir ki satıcının zapttan sorumluluğu, mülkiyeti ve zilyetliği devir borcunun ihlaline bağlanan bir yapt1rımdir $^{7}$. Dolayısıyla ancak bu borcun varlığı zapttan sorumluluğa anlam kazandırabilir ${ }^{8}$. Satış konusunun, satıcı tarafından alıcının malvarlığına aktarılamamasından ileri gelen bu sorumluluk esas itibarıyla satıcının tasarruf yetkisinin eksikliğinden kaynaklanır?.

Zapttan sorumluluk doğrudan doğruya yasa tarafindan öngörülmüş olup kural olarak tarafların ayrıca sözleşmede kararlaştırmasını gerektirmez ${ }^{10}$. Genel hükümlerde düzenlenen sorumluluk rejiminden farklı olarak zapttan sorumluluk, tam zaptta alıcının dolaylı zararlarının giderilmesi dışındaki zararlar bakımından kusurdan bağımsız bir sorumluluk halidir ${ }^{11}$. Özellikle bu yönden zapttan sorumluluğun genel hükümlere nazaran alıcı lehine olduğu ifade edilmektedir ${ }^{12}$.

Zapttan sorumluğun söz konusu olması için üçüncü kişinin üstün bir hak sahibi olması gereklidir ${ }^{13}$. Hangi hakların "üstün” sayılabileceği aşağıda incelenecektir. Bu özelliğe burada değinilmesinin sebebi, üçüncü kişinin hakkının varlı̆̆ının zaptın hukuki ayıptan ayrım yapmayı sağlıyor olmasıdır. Zaptta, satılan, alıcının elinden üçüncü kişinin üstün hakkını ileri sürmesi nedeniyle alınır. Mesela, hırsızlık soruşturması kapsamında kolluk kuvvet-

Besonderer Teil, Band I Die einzelnen Vertragsverhältnisse Art. 184-318 OR, Bern, 2012, §1 N. 61; Bucher, Eugen: Obligationenrecht, Besonderer Teil, Zürih 1988, s. 90.

7 CR-Venturi/Zen-Ruffinen, Intro. Art. 192-196a CO, N. 1; Tandoğan, s. 148; Yavuz, s. 110; Aral/Ayrancı, s. 107; Acar, Özlem: "Satıcının Zapttan Sorumluluğu", İstanbul Kültür Üniversitesi Hukuk Fakültesi Dergisi, C. 13 S. 1 (2014), s. 104; Aydoğdu/ Kahveci, s. 119; Çabri, s. 587. Bununla birlikte zapt halinin eksik ifa oluşturduğunu ileri sürmek kanımızca mümkün değildir. Karş. Tunçomağ, s. 209.

8 Tandoğan, s. 149; CR-Venturi/Zen-Ruffinen, Intro. Art. 192-196a CO, N. 1.

9 CHK-Hrubesch-Millauer, Art. 192 OR, N. 2; OFK Orell Füssli Kommentar (Navigator.ch)- Kostkiewicz, Jolanta Kren: OR Kommentar Schweizerisches Obligationenrecht, Zürih, 2016, Art. 192 OR, N. 1-2.

10 Tandoğan, s. 148; Yavuz, s. 110; Aral/Ayrancı, s. 107; Aydoğdu/Kahveci, s. 120; Zevkliler/Gökyayla, s. 141; Doğu, s. 520. Bu durum sorumluluğun kökenini sözleşmesel olmaktan çıkarmaz: Nomer/Engin, TBK m. 214, N. 3.

11 Tandoğan, s. 149; Yavuz, s. 111; Eren, N. 229; Hatemi/Serozan/Arpacı, s. 80; Engel, Pierre: Contrats de droit suisse, Bern, 2000, s. 28; BSK-Honsell, Vorb. Art. 192-210 OR, N. 1; Tercier, Pierre/Venturi, Silvio: Les contrats speciaux, Zürih, 1995, N. 324.

12 BSK-Honsell, Vorb. Art. 192-210 OR, N. 1 Eren, N. 232; Engel, s. 27; BK-Giger, Art. 192 OR, N. 7.

13 CR-Venturi/Zen-Ruffinen, Art. 192 CO, N. 5; BSK-Honsell, Vorb. Art. 192-210 OR, N. 5; Huguenin, Claire: Obligationenrecht Allgemeiner und Besonderer Teil, Zürih, 2014, N. 2552; Koller, §4 N. 74. 
lerinin satılana el koyması zapt hükümlerinin uygulanmasına sebep olma$11 d ı r^{14}$. Zira bu durumda üçüncü kişinin üstün hakkı nedeniyle alıcının satılandan yararlanmasına engel olunmaktadır. Bu kapsamda üçüncü kişinin şikâyeti de üstün hakkın ileri sürülmesi olarak değerlendirilebilir. Buna karşılık hukuki ayıp söz konusu olduğunda alıcı, satılandan hukuk düzeninde öngörülmüş bulunan genel bir sınırlama sebebiyle sözleşmede öngörüldüğü surette yararlanamaz. Farklı bir deyişle, alıcının satılandan yararlanmasını engelleyen başkasının hakkı değildir, bizatihi hukuk düzeninin içerdiği normlardır ${ }^{15}$. Örnek olarak, teknik şartlara aykırı olarak üretildiği için bir cihazın kullanımının yasaklanmış olması, yapı inşa etme üzere satın alınan

14 Yarg. 13. HD., 12.3.2018, 37842/2924 (Lexpera); Yarg. 13. HD., 20.12.2011, 13524/ 19637 (Kazanc1); Yarg. 13. HD., 7.2.2019, 18254/1399 (Kazanc1); Yarg. HGK., 7.6.2000, 13-924/946 (Kazanc1); Yarg. 13. HD., 7.2.2012, 18722/2295 (Lexpera); Yücedă̆, Nafiye: Sözleşmeye Aykırı Mal Tesliminde Yenisiyle Değiştirme Hakkı TBK ve CISG Uyarınca, İstanbul, 2018, s. 64. Ancak bu durumda yargılama sonucu beklenilmelidir. Zira zapt olgusu yargılama sonunda verilecek hükümle tamamlanacaktır. Bkz. Yarg. 13. HD., 13.3.2013, 56/6242 (Kazanc1); Keza tedbiren ceza mahkemesince el konulmanın zapta yol açamayacağı hakkında: Yarg. 13. HD., 27.5.2002, 1787/6171 (Kazancı); Çalıntı otomobile farklı şasi numarası çakılması halinde hukuki ayıp olduğu şeklinde: Yarg. 13. HD., 1.7.2013, 13389/18038 (Kazanc1).

15 Tandoğan, s. 152; Engel, s. 29; Aral/Ayrancı, s. 108; Gümüş, s. 53; Acar, s. 104; Kapancı, Kadir Berk: Satış Hukukunda Ayıptan Doğan Sorumluluk ve Sözleşmesel Garanti Taahhütleri, İstanbul, 2012, s. 13 ve dn. 43; Koller, §4 N. 74; Kızllay, Aygül: "Türk Borçlar Kanunu ile Milletlerarası Mal Satımına İlişkin Sözleşmeler Hakkında Birleşmiş Milletler Antlaşması (CISG) Hükümleri Çerçevesinde Satış Sözleşmesinde Ayıptan Sorumlulukta Alıcının Seçtiği Hakkın Sonradan Değiştirilebilirliği Sorunu”, Hacettepe HFD 7(2) 2017, s. 197 ve dn. 6. Kamu hukuku kaynaklı bir sinırlama olduğu şeklinde: BSK-Honsell, Art. 192 OR, N. 2; OFK-Kostkiewicz, Art. 192 OR, N. 2, yazar zaptta satıcının tasarruf yetkisinde eksiklik bulunduğunu, hukuki ayıpta ise genel bir hukuki niteliğin eksikliğinin söz konusu olduğunu vurgulamaktadır. Kamu hukukundan doğan standartlara aykırı mal tesliminin hukuki ayıp oluşturacağı şeklinde: Şahiniz, Salih: Tacirler Arası Ticari Satımlarda Satıcının Ayıplı İfadan Sorumluluğu, Ankara, 2008, s. 48; Yavuz, Cevdet: Satıcının Satılanın Ayıplarından Sorumluluğu, İstanbul, 1989, s. 62; Yücedağ, s. 63-64; Usulsüz ithalat nedeniyle satılana el konulması da hukuki ayıp oluşturur: Yarg. 19. HD., 9.5.2016, 12073/8453 (Lexpera). Karş. Yarg. 13. HD., 26.6.2019, 2006/7761 (Kazanc1): "İşlem tarihinde yürürlükte olan 818 Sayılı BK'nun 189 (yeni BK 214) maddesinin birinci bendinde, "Bayi, satılan şeyin bir üçüncü şahıs tarafından bey'in akdi zamanında mevcut bir hak sebebi ile tamamen veya kısmen zaptedilmesinden alıcıya karşı mes'ul ve zamindir.” hükmü yazılıdır. Madde metninden de açıkça anlaşılacağı gibi mevcut ayıp ister subjektif bir haktan, isterse objektif bir hukuk kuralından doğmuş olsun satıcı, devrini taahhüt edip gerçekleştirdiği hakkın kendi malvarlığında mevcut olup olmamasından sorumludur. Devredilen hak, herhangi bir nedenle devri taahhüt edilen hakka uygunluk göstermiyorsa satıcı bundan sorumludur. Bu sorumlulukta alıcının zapt nedeniyle uğradığı gerçek zarar kadardır.”. 
arsada imar yasağı nedeniyle inşaat yapılamıyor olması hukuki ayıp teşkil eder $^{16}$. Benzer şekilde trafik siciline kaydedilmiş hurda aracın şasi numarasının değiştirilmiş olması (çenç otomobil) de hukuki ayıp oluşturmak$\operatorname{tad}_{11}{ }^{17}$. Zira araçtan yararlanılmasını engelleyen başkasının hakkı değil, şasi numarasının değiştirilmesidir.

\section{ZAPTTAN SORUMLULUĞUN MADDİ KOŞULLARI}

\subsection{Hüküm İfade Eden Bir Satış Sözleşmesinin Kurulmuş Olması}

Satıcının zapttan sorumluluğuna gidilebilmesinin mantıksal olarak ilk koşulu hüküm ifade eden bir satış sözleşmesinin varlı̆̆ıdır ${ }^{18}$. Sözleşme hiç kurulmamış ise, TBK m. 27 uyarınca ${ }^{19}$ kesin hükümsüz ise yahut irade bozukluğu nedeniyle iptal ya da temerrüt nedeniyle sözleşmeden dönme sonucu hükümden düşmüş ise kural olarak sadece olumsuz zararın giderilmesine yönelik bir istem ileri sürülebilir, satılanın teslimi ve bununla ilişkili diğer talepler ileri sürülemez ${ }^{20}$. Özellikle, özel mülkiyete tabi olmadığ satı̧s sözleşmesine konu edilemeyecek eşyalar bakımından bu sonuca varılması zorunludur. Zira böyle bir satış sözleşmesi konusu itibarıyla TBK m. 27'ye aykırıdır²1. Buna karşılık Yargıtay uygulamasında, Maliye Hazinesi

16 Huguenin, N. 2552; BSK-Honsell, Art. 192 OR, N. 2; JdT 1970 I 238: "Somut olayda bir yandan, makinanın idari düzenlemelere uygun olmadiğl, alıcı tarafindan teslim ve satıcı tarafindan kurma yeri olan Cenevre'de kullanılamayacă̆l sabittir. Diğer yandan, elektrik aksamına ilişkin koşulların İsviçre'de bölgeden bölgeye bazen de önemli ölçüde değiş̧tiği ortaya konmuştur. Buradan makinanın (çalışması gerektiği yerdeki işlevselliğini ortadan kaldıran) bir hukuki ayıp taşıdiğı sonucuna ulaşılmalıdır.”; JdT 1973 I 370; Yarg. 13. HD., 3.12.2015, 28311/35520 (Lexpera).

17 Yarg. 13. HD., 27.6.2005, 4861/10819 (Kazanc1). Yargitay hurda (pert kaydı olan) aracın satışını TBK m. 27'ye aykırı görmemiştir. Aynı yönde: Yarg. 13. HD., 8.6.2016, 9187/14705 (Lexpera). Ayrıca bkz. Zevkliler/Gökyayla, s. 117. Aksi yönde: Yarg. 13. HD., 2.12.2015, 40668/35250 (Lexpera).

18 Eren, N. 240; Nomer/Engin, TBK m. 214, N. 31; Gümüş, s. 55; Çabri, s. 591; Yavuz, s. 111; CR-Venturi/Zen-Ruffinen, Intro. Art. 192-196a CO, N. 6.

19 Bu hususta mevcut olmayan alacağın devri halinde bir istisna öngörülmüş olup başlangıçtaki objektif imkânsızlık nedeniyle kesin hükümsüzlük söz konusu olmamaktadır. Cavin, Pierre: Traite du Droit Prive Suisse - VII-1 - La Vente L'Echange La Donation, Friburg, 1978, s. 64; Engin, Baki İlkay: Alacağın Temlik Edenin Garanti Sorumluluğu, Ankara, 2002, s. 84 vd.

20 Yavuz, s. 111; Aral/Ayrancı, s. 109; Gümüşs, s. 55; BSK-Honsell, Art. 192 OR, N. 4; BK-Giger, Art. 192 OR, N. 38-39; Yarg. 13. HD., 18.9.2008, 4066/10729 (Kazanc1); Hilede: Ercoşkun Şenol, Hile, s. 90; Tandoğan, s. 149.

21 Yarg. 13. HD., 15.12.2009, 6712/14866 (Lexpera): "Yukarıda ayrıntılı şekilde açıklandığ 1 üzere, davalı tarafın, davacı K1'a sattığı taşınmazın, baştan beri hukuksal nitelikçe bir kamu malı olduğu, üzerinde özel mülkiyet kurulması sonucunu doğuracak şekilde 
veya Orman İdaresi tarafindan açılan davalar sonucunda, kamu mülkiyetine tabi olduğu tespit edilen taşınmazların alıcılarının satıcının zapttan sorumluluğuna gidebileceklerinin kabul edildiği gözlemlenmektedir ${ }^{22}$.

Hakkında ceza mahkemesi tarafindan müsadere kararı (TCK m. 54 ve 55) verilmiş eşyalar da satış sözleşmesine konu edilemez ${ }^{23}$. Ancak satış sözleşmesi kurulduğu sırada böyle bir karar yoksa ve daha sonra verilen bir karar sonucunda müsadere gerçekleşirse, hukuki ayıba ilişkin sonuçların doğması yerinde olacaktır. Zira sözleşme kurulduğu anda hukuka aykırılık yoktur. Üçüncü kişinin de üstün hak iddiası yoktur. Ancak eşyanın müsaderesine ceza yargılaması sonucunda karar verilmesi, alıcının satılandan beklenen yararı elde etmesini engelleyen bir hukuki durum oluşturmaktadır ${ }^{24}$.

alım satıma konu edilemeyeceği; bu sonucu sağlamaya yönelecek şekilde sözleşmeler yapılamayacağı kuşkudan uzaktır. Başka bir ifadeyle, kanun, tüm diğer kamu malları gibi, anılan taşınmaz yönünden de bu nitelikte sözleşmeler yapılmasını yasaklamış ve sözleşme serbestisini bu yönden sınırlamıştır. Kanunun yasakladığ sözleşme ise, BK.nun 19 ve 20.maddelerinin birlikte değerlendirilmesinden ve özellikle 1O.maddedeki “... batıldır” sözünden çıkan sonuca göre, mutlak butlanla malüldür; eş söyleyişle, yapıldığı andan itibaren geçersizdir.”. Aynı yönde: Yarg. 13. HD., 30.4.2009, 14776/5932 (Lexpera).

22 Örnek olarak: Yarg. 13. HD., 26.6.2019, 2006/7761 (Kazanc1); Yarg. 13. HD., 12.6.2019, 17373/7094 (Kazanc1); Yarg. 13. HD., 18.10.2011, 10397/14600 (Kazanc1); Yarg. 13. HD., 15.9.2011, 10479/12688; Yarg. 13. HD., 27.6.2011, 2156/10211 (Kazanc1); Yarg. HGK., 15.12.2010, 13-618/668 (Kazanc1); Yarg. 13. HD., 26.6.2019, 2006/7761 (Kazanc1), kararda yer alan işlem tarihinde yürürlükte olan 818 Sayılı BK'nun 189 (yeni BK 214) maddesinin birinci bendinde, "Bayi, satılan şeyin bir üçüncü şahıs tarafından bey'in akdi zamanında mevcut bir hak sebebi ile tamamen veya kısmen zaptedilmesinden alıcıya karşı mes'ul ve zamindir.” hükmü yazılıdır. Madde metninden de açıkça anlaşılacağı gibi mevcut ayıp ister subjektif bir haktan, isterse objektif bir hukuk kuralından doğmuş olsun satıcı, devrini taahhüt edip gerçekleştirdiği hakkın kendi malvarlığında mevcut olup olmamasından sorumludur. Devredilen hak, herhangi bir nedenle devri taahhüt edilen hakka uygunluk göstermiyorsa satıcı bundan sorumludur. Bu sorumlulukta alıcının zapt nedeniyle uğradığı gerçek zarar kadardır." ifadesi hem zapt hükümlerinin uygulanması hem de zaptın kapsamına hukuki ayıbın sokulması açısından eleştiriye açıktır. Ayrıca bkz. Gümüş, s. 55; Çabri, s. 587-588, yazar orman sınırları içinde kalan taşınmaza ilişkin olarak tam zaptın gerçekleşmeyeceği, taşınmazın özel mülkiyete uygun bir vasıf kazanmayacağı hususlarını vurgulamaktadır.

23 Yarg. 13. HD., 2.7.1986, 2945/4167 (Kazanc1): “Taraflar arasında satış sözleşmesi 12.8.1978 tarihlidir. Satış konusu traktörün davacı ile davalı arasındaki satış akünden önce işlenen Orman Kanununa aykırı fiilden dolayı 9.3.1982 tarihinde Sulh Ceza Mahkemesince müsaderesine karar verilmiş ve araç davacıdan alınmıştır. Böylece olayda satış aktinin konusu orman suçunda kullanılan aracın satışına ilişkin olup BK.nun 20.maddesi hükmü gereğince satış, konusu itibariyle hukuka aykırı ve batıldır.”.

24 Eşya müsaderesinde, müsadereye konu olan eşyaların suçun işlenme tarihi itibarıyla mülkiyet durumunun nazara alındığı sonraki değişiklere bakılmadığı hakkında bkz. 
Mesela, cinayette kullanılan değerli bir kılıç bu durum bilinmeden satılır ve mülkiyeti devredilirse, daha sonra cinayet yargılamasında kılıcın suç aleti olduğu gerekçesiyle müsadere edilmesi halinde hukuki ayıp hükümleri uygulanabilir. Bu bağlamda müsadereye (TCK m. 54-55) konu edilebilir olmak, fikrimizce, kendi başına hukuki ayıp oluşturmaktadır. Nihayet bu çerçevede özel olarak değerlendirilmesi gereken diğer bir olasılık da gümrük mevzuatına aykırılık nedeniyle Kaçakçılıkla Mücadele Kanunu kapsamında el konulan eşyalara ilişkin satış sözleşmelerinin akıbetidir. $\mathrm{Bu}$ akıbete göre ya hukuki ayıp hükümleri üçüncü kişinin hakkının yokluğu nedeniyle uygulanacak ya da hükümsüzlük ${ }^{25}$ nedeniyle sözleşmeden herhangi bir borç doğmayacaktır. Kaçakçılıkla Mücadele Kanunun 16. maddesi "müsadere yaptırımının uygulanabileceği eşya, sahibine iade edilemez" hükmünü taşımaktadır. $\mathrm{Bu}$ durumda satılanın elinden alındığı kişinin (alıcının), yasakoyucu tarafindan malik olarak kabul edildiği yorumu yapılabilir. Nitekim kanunun yürürlüğün önceki dönemlerde Yargıtay bazı kararlarında gümrük mevzuatına aykırılık nedeniyle el konulan araçlara ilişkin davalarda satış sözleşmesini hükümsüz saymamıştır ${ }^{26}$. Bu bakımdan gümrük mevzuatına aykırılık hukuki ayıp oluşturur yorumu yapılabilir ${ }^{27}$. Kaldı ki Kaçakçılıkla Mücadele Kanununun 13. maddesinin yollamasıyla uygulanacak suçun konusunun müsaderesine ilişkin TCK m. 55 hükmünün son fıkrası, Türk Medeni Kanunu uyarınca hak kazanan iyiniyetli üçüncü kişilerin edinim-

Baytaz, Abdullah Batuhan: Türk Ceza Hukukunda Müsadere (TCK m. 55-54), Yüksek Lisans Tezi, İstanbul, 2009, Marmara Üniversitesi Sosyal Bilimler Enstitüsü, s. 77; Bu durumda zaptın söz konusu olacağı yönünde: Yarg. 13. HD., 17.4.2007, 223/5390 (Kazanc1): “...davacının davalı adına kayıtlı otoyu geçerli satış sözleşmesi ile satın aldığı ancak dava dışı aracın ilk malikinin eylemleri nedeniyle araç hakkında müsadere kararı verilerek aracın davacının elinden alındığı hususları dosya kapsamı ile sabittir. $\mathrm{Bu}$ durumda; davacı alıcının akidi olan satıcı davacının zararını karşılamak zorundadır. Davacının zararı ise; satılanın zaptından dolayı aracın elinden alınması nedeniyle uğradığı zarardı ki bu da aracın el konulma tarihindeki rayiç bedelidir." Karş. Müsaderenin zapta yol açacağ 1 fikrinde: OFK-Kostkiewicz, Art. 192 OR, N. 4.

25 Kaçak araç satış sözleşmesinin hükümsüz olduğu görüşünde: Yarg. 13. HD., 27.12.1988, 6846/6479 (Kazanc1); Geçerli olduğu ve zapta yol açacağ1 yönünde: Yarg. 13. HD., 7.3.2018, 25772/2895 (Lexpera).

26 Yarg. 11. HD., 25.5.1989, 351/3111 (Kazanc1); Yarg. HGK., 24.1.2007, 19-25/21 (Kazanc1).

27 Yarg. 13. HD., 25.1.2018, 26579/656 (Lexpera); Yarg. 19. HD., 31.1.2018, 14307/266 (Lexpera); Yarg. 13. HD., 7.5.1981, 1942/3498 (Kazanc1); Zapt hükümlerinin uygulanabileceği fikrinde: Türker, Erhan: Türk ve İngiliz Hukukunda Satıcının Zapta Karşı Teminat Borcu, Eskişehir, 1974, s. 83. 
lerini korumak suretiyle, bu eşyalara ilişkin işlem yapılabileceğinin kabul edildiğini göstermektedir.

\subsection{Zapttan Sorumluluğa İliş̧kin Bir Sorumsuzluk Anlaşması Yapılmamış Olması}

Zapttan sorumluluk TBK m. 214/III düzenlemesinden anlaşıldığı üzere kural olarak emredici değildir ${ }^{28}$. Dolayısıyla zapttan sorumluluğun söz konusu olabilmesi için sorumsuzluk anlaşmasının bulunmaması gereklidir ${ }^{29}$. $\mathrm{Bu}$ anlaşma sözleşme kurulurken de yapılabileceği gibi satış sözleşmesinin tadili zımnında sözleşmenin kurulmasından sonra da yapılabilir. Ancak zaptın koşulları gerçekleştikten sonra ${ }^{30}$ bu yönde yapılacak bir sözleşme sorumsuzluk anlaşması hükmünde olamaz. Ancak sulh anlaşması veya ibra sonucunu doğurabilir ${ }^{31}$ ve bu nedenle geçerliliği sorumsuzluk anlaşmasının koşullarına tabi olmaz.

28 Yavuz, s. 110; Eren, N. 238; Hatemi/Serozan/Arpacı, s. 84; Engel, s. 32; Schmid, Jörg: "Die Gewährleistung beim Grundstückkauf Ausgewählte Fragen unter Berücksichtigung von Altlasten", Schweizerische Zeitschrift für Beurkundungs- und Grundbuchrecht, S. 81, 2000, s. 357; Türker, s. 50 vd.; CR-Venturi/Zen-Ruffinen, Intro. Art. 192-196a CO, N. 7; Nomer/Engin, TBK m. 214, N. 4.

29 Genel olarak, sorumsuzluk anlaşmasının tasarruf işlemi niteliğinde olduğu ifade edilmektedir. Bkz. Akman, Galip Sermet: Sorumsuzluk Anlaşması, İstanbul, 1976, s. 13; Başalp, Nilgün: Sorumsuzluk Anlaşmaları, İstanbul, 2011, s. 38-39; Erten, Ali: Türk Sorumluluk Hukukunda Sorumsuzluk Şartları, Ankara, 1977, s. 90. Kanımızca öncelenmiş de olsa bir tasarruf işlemini tereddütsüz olarak kabul etmek güç olacaktır. Zira bu kabule göre aslında sorumsuzluk anlaşması sonuç itibarıyla ibra niteliğinde olacaktır. Oysa ortada işlemin konusunu oluşturacak tazminat alacağının henüz doğmamış, doğmasının muhtemel olması halinde belirlilik yönünden bir geçerlilik tartışması doğabilir. Gelecekteki alacakların devri bağlamında bkz. Nomer, Haluk N.: Beklenen Haklar Üzerindeki Tasarrufların Hukuki Sonuçları, İstanbul, 2002, s. 108-109. Bu konuda ayrıca: Antalya, O. Gökhan/Sağlam, İpek: Miras Hukuku, İstanbul, 2015, s. 45 vd. Esasen burada hakkın doğumuna temel oluşturacak hukuki yapının, sözleşmenin hükümlerinin çerçevesinin çizildiği kabul edilebilir. Bu durumda bir hakta öncelenmiş bir tasarruf söz konu olmayacaktır. Bkz. Vionnet, Guillaume: L'exercice des droits formateurs, Zürih-Basel-Cenevre, 2008, s 103-104. Yazar, yenilik doğuran hakların doğumundan önce feragat meselesini incelerken, konuya bu açıdan yaklaşmakta ayrıca doğmuş yenilik doğuran haklardan tek yanlı feragatin mümkün olduğu halde doğmamış yenilik doğuran haklarından feragatin sözleşme ile yapılabilmesinin işlemler arasında hukuki nitelik farkı olduğuna işaret etmiştir. Bu bağlamda zapttan sorumluluğa da genişletilebilecek şekilde, ayıba karşı tekeffüle ilişkin sorumsuzluk anlaşmalarında öncelenmiş bir tasarruf işleminin değil, bir hakkın düzenlediğini belirtmektedir. Karş. Hasar ve yararın geçmesinden sonra: OFK-Kostkiewicz, Art. 192 OR, N. 9; ATF 130 III 686.

31 Başalp, s. 72-73; Erten, s. 92. 
TBK m. 214/III uyarınca zapta ilişkin sorumsuzluk anlaşması, satıcının üçüncü kişinin hakkını gizlediği ${ }^{32}$ takdirde kesin hükümsüzdür ${ }^{33}$. Bu düzenleme sorumsuzluk anlaşmalarına ilişkin genel düzenlemelerden sapmakta olduğundan uygulama alanı açısından yürürlükten kalkan Borçlar Kanunu döneminde yapılan tartışma ${ }^{34}$ yine sürecektir ${ }^{35}$. Oysa yürürlükteki Türk Borçlar Kanunu'nda ayıba ilişkin sorumlulukta ise genel hükümlerle uyum sağlanmıştır. Zapta ilişkin bu düzenlemeden kaçınılması ise eleştiriye açık bir seçimdir. Böyle bir gereksinimin nereden doğduğuna ilişkin açıklık bulunmamaktadır.

TBK m. 214/III hükmünün özel düzenleme sayılması ile, zapttan sorumluluğun kastın olmadığ her durumda tam olarak sona erdirilmesinin kabul edilmesi halinde, alıcı lehine olan tekeffül düzenlemelerinin amacı dışına çıkacağı, bağışlama sözleşmesinde dahi ağır kusurdan sorumsuzluğun bertaraf edilemediği hukuk düzeninde kabul edilemez olacağı görüşü öğretide savunulmuştur ${ }^{36}$. Kanımızca, açık lafız nedeni ile TBK m. 214/III'te sadece "zapt tehlikesinin bilinmesi halini" düzenlediğinin savunulması için yeterli dayanak bulunmakla birlikte, bu kabul, ileri sürüldüğü gibi, yasa sistematiğini tehlikeye sokacak etkiye sahip olamaz. Zira alıcının zapta ilişkin yaptığı sorumsuzluk anlaşması salt zapta ilişkin hükümlere başvurmasını

32 Bilerek gizlemenin hileli gizleme ile eş anlamlı olduğu hakkında: Schmid, s. 358; Pasif hile şeklinde de gerçekleşebileceği hakkında: Tunçomağ, s. 225; Satıcının ağır ihmalinin kasıtla gizlemek anlamına gelmeyeceği: Eren, N. 291 ancak yazar, satıcının gerekli özeni göstermiş olsaydı üstün hakkı bilebilecek konumda olması halinde üçüncü kişinin hakkının gizlenmiş olabileceğini de belirtmektedir. Ağır ihmalin yeterli olmadığı: CHK-Hrubesch-Millauer, Art. 192 OR, N. 5; CR-Venturi/Zen-Ruffinen, Art. 192 CO, N. 9; BK-Giger, Art. 192 OR, N. 75; BSK-Honsell, Art. 192 OR, N. 8. Satıc1nın satılanın her zayıflığını açıklamak zorunda olmadığı ancak makul bir satıcının belirteceği veya en azından sorumsuzluk anlaşması yapmayacağı derecedeki haller için de sorumsuzluk anlaşmasının hükümsüz olması gerektiği görüşü: Bucher, s. 85. Aleyhine açılmış davadan haberdar etmemenin kasten gizleme sayılacağı: Yarg. 13. HD., 11.10.2004, 4841/14134 (Lexpera).

Zevkliler/Gökyayla, s. 142; CR-Venturi/Zen-Ruffinen, Art. 192 CO, N. 9; BSKHonsell, Art. 192 OR, N. 8; Schmid, s. 358.

35 TBK m. 27 ve TBK m. 115'e aykırılık halinde de hükümsüzlüğün söz konusu olacağ1 görüşünde: Eren, N. 293-394; Hükmün lafzı esas alındığında ağır kusurun hükümsüzlüğe yol açmayacağı görüşünde: Gümüş, s. 57.

Akman, s. 107-108; Tunçomağ, s. 226; Benzer şekilde TBK m. 115-116 hükümleriyle sınırlı olduğu görüşünde: Kılıçoğlu, Ahmet M.: Borçlar Hukuku Özel Hükümler, Ankara, 2019, s. 68; Eren, N. 294; OFK-Kostkiewicz, Art. 192 OR, N. 8; Huguenin, N. 2569; Bucher, s. 84. 
engelleyecek, alıcıyı genel hükümler uyarınca satıcıyı sorumlu tutmaktan alıkoyamayacaktır ${ }^{37}$. Ancak zapttan doğan sorumluluğun sadece sınırlandırılması söz konusu ise, bu durumda yine tam zapt durumunda sözleşme sona ermiş sayılacağından genel hükümlere başvurma yolu, fikrimizce, kapanır. Bu olasılıkta da genel hükümleri de kapsayan bir sorumsuzluk anlaşmasının bulunduğu sonucuna varılarak, TBK m. 115 hükmüne işlerlik kazandırmak gerekir.

Alıcı hakkını, sorumsuzluk anlaşmasının hükümsüzlüğ̈̈ vakısına dayandırdığından, satıcının üstün hakkı gizlemesi vakıası alıcı tarafından kanitlanmak gerekir ${ }^{38}$.

\subsection{Alıcının Zapt Tehlikesini Bilmemesi}

TBK m. 214/II uyarınca, alıcı zapt tehlikesinden satış sözleşmesinin kurulduğu anda ${ }^{39}$ haberdar $^{40}$ ise kural olarak satıcı zapttan sorumlu olmaz; meğerki satıcı bu hususta açık bir taahhütte bulunsun ${ }^{41}$. Bunun güven

37 Akman, s. 108. Ancak yorum yolu ile sorumluk anlaşmasının olası diğer sorumluluk sebeplerini de kapsadığı sonucuna ulaşıliyorsa bu durumda kuşkusuz genel hükümlere gidilemez. Fakat bu durumda söz konusu sorumluluk anlaşmasının geçerliliği de genel hükümlere tabi olur. Her halükarda sorumsuzluk anlaşmasının kapsamı sözleşmenin yorumuna bağlı olarak anlaşılabilir: Tunçomağ, s. 226; OFK-Kostkiewicz, Art. 192 OR, N. 9; ATF 126 III 59.

CR-Venturi/Zen-Ruffinen, Art. 192 CO, N. 2; BSK-Honsell, Art. 192 OR, N. 9.

BK-Giger, Art. 192 OR, N. 47; Durumun sonradan öğrenilmesi satıcının sorumluluğunu etkilemez. Bkz. BSK-Honsell, Art. 192 OR, N. 5.

Eğer kısmi zapt tehlikesi hususunda bilgisi varken tam zapt gerçekleşirse, tazminatın belirlenmesi kapsamında bu durum indirim sebebi olarak dikkate alınmak gerekir. Bununla birlikte zapt tehlikesini bilen alıcının kurduğu sözleşmenin amacındaki hukuka veya ahlaka aykırılık nedeniyle kesin hükümsüz sayılma olasılığı öncelikle değerlendirmek lazım gelir: Nomer/Engin, TBK m. 214, N. 41.

Yarg. 13. HD., 21.3.1995, 1837/2797 (Kazanc1): "Somut olayda. M.K.nun 931. maddesi hükmü uyarınca tapu kaydına güvenerek davalıdan iyi niyetle taşınmazı satın aldığını ileri süren davacının satım aktini yaptığı 4.10.1986 tarihinde 3. şahıs Ali Kalay'ın bu taşınmaz üzerinde hakkını, dolayısıyla taşınmazın kendisinden önce Ali Kalay'a satıldığını bildiği iyi niyetli sayılamayacağı M.K.nun 931 maddesi hükmündeki korumadan yararlanamayacağı gerekçesiyle aleyhine açılan tapu iptal ve tescil davasının kabul edilerek kesinleşmiş olması karşısında davacının davalı ile 4.10.1986 tarihinde yaptığı satış akdinin inikadı sırasında zabıt tehlikesini bildiği ve iyi niyetli olmadığının kabulü zorunludur. Zabit tehlikesini bilen davacı bu davada, davalının ayrıca kefaletinin bulunduğunu iddia ve isbat edemediğine göre olayda davalı satıcının, davacı alıcıya karşı satılanın zaptından dolayı zapta karşı tekeffül hükümleri gereğince bir sorumluluğunun varlığından söz edilemez. “; Tandoğan, s. 155; Zevkliler/Gökyayla, s. 142; Gümüss, s. 56; Cavin, s. 66; CR-Venturi/Zen-Ruffinen, Art. 192 CO, N. 6; BK-Giger, Art. 192 
ilkesinin bir yansıması olduğu düşünülebilir. Alıcının zapt tehlikesinden haberdar olduğunu bilerek sözleşmeyi akdettiğini bilen satıcı sözleşmeye zapttan sorumlu tutulmayacağı anlamını haklı olarak verebilir ${ }^{42}$. Buna karş11ık bu tespit, durumu tam olarak yansıtmamaktadır. Zira satıcının, alıcının zapt tehlikesinden bilgisi olduğunu bilmesine gerek yoktur.

Alıcının zapt tehlikesini bildiğinin kabul edilebilmesi için üçüncü kişinin hak iddiasının hukuki kapsam ve önemi hakkında tam bir bilgi sahibi olması zorunlu değildir ${ }^{43}$. Diğger yandan satıcının sorumluluktan kurtulabilmesi için, alıcının zapt tehlikesine ilişkin bilgisi belirli bir kişinin hak iddiasında bulunduğuna ilişkin ise, zaptın bu kişi tarafından gerçekleştirilmesi icap eder ${ }^{44}$. Alıcının bilgisi salt bu tehlike ile sınırlı olduğundan, başka kişilerden gelen zapt tehlikesinden haberdar addedilemez. Başka bir deyişle sorumluluğun kalkması, alıcının bilgisiyle sınırlıdır.

Alıcının bilmesi gereken zapt tehlikeleri açısından da satıcının sorumluluğunun doğup doğmayacağı hususu öğretide tartışmalıdır ${ }^{45}$. Her iki yönde de görüş bulunduğu gibi ağır kusur ile bilgi edinmekten kaçınılması duru-

OR, N. 34; Yavuz, s. 117. Bu durumda sorumluluğun kapsam ve koşulları öncelikle taahhüde göre belirlenmek gerekir: Nomer/Engin, TBK m. 214, N. 40; ZK-Schönle/ Higi, Art. 192 OR, N.49.

42 Çabri, s. 597; Feyzioğlu, Feyzi N.: Borçlar Hukuku İkinci Kısım Akdin Muhtelif Nevileri Cilt I, İstanbul, 1980, s. 253; Karş. BK-Giger, Art. 192 OR, N. 46, Yazar, satış sözleşmesinin bu koşullarda kurulması halinde, alıcının zapttan doğan haklarından feragat ettiğine ilişkin kanundan doğan bir karinenin bulunduğunu belirtmektedir.

43 BK-Giger, Art. 192 OR, N. 48.

44 BK-Giger, Art. 192 OR, N. 49.

45 CHK-Hrubesch-Millauer, Art. 192 OR, N. 5; BSK-Honsell, Art. 192 OR, N. 5; Bilmemek ile bilme yükümlülüğünün farklı olduğu görüşünde: Tandoğan, s. 155; Feyzioğlu, s. 253; Tunçomă̆, s. 224 Yasanın bilme gerekmesi halinde açık hüküm sevk ettiği, müsbet vukufun iyiniyetle eş şekilde değerlendirilemeyeceği görüşünde: Cavin, s. 66; OFK-Kostkiewicz, Art. 192 OR, N. 7; Tercier/Venturi, N. 322; Schumacher, Rainer/Rüegg, Erich: "§ 5 Die Haftung des Grundstückverkäufers / III.IV.”, Der Grundstückkauf, 2. Bask1, Bern, 2001, Editör: Alfred Koller, N. 97; Türker, s. 88; Ağır kusur halini de kapsam dâhilinde sayan görüş: Engel, s. 29; Hatemi/ Serozan/Arpacı, s. 82; Müspet vukfun gerekli olduğu şeklinde: CR-Venturi/ZenRuffinen, Art. 192 CO, N. 6; Karş. BK-Giger, Art. 192 OR, N. 54, Yazar düzenlemenin amaçsal olarak alıcının zapt tehlikesini bilmesi gerektiği halleri de kapsaması gerektiği, ancak satıcının aydınlatma yükümlülüğü nazara alındığından alıcının ihmali nedeniyle durumu bilmediği ihtimallerde yine satıcının zapttan sorumlu tutulabileceğini, alıcının kasıtlı olarak bilgi edinmekten kaçınması halinde zapttan sorumluluğun söz konusu olmayacağı görüşündedir. Bilmesi gerekmenin de sorumluluğu ortadan kaldıracağ fikrinde: Kılıçoğlu, s. 67; Eren, N. 242; Çabri, s. 597-598. 
munda ${ }^{46}$ da zapt sorumluluğunun söz konusu olmayacağı savunulmaktadır ${ }^{47}$. Kanımızca bilmenin gerekmesi hallerinde zapttan sorumluluğu ortadan kaldırmasının kabul edilmesi, zapt hükümlerinin dar olan çerçevesini daha da daraltmış olacaktır. Hatta bu durumda zapt hükümleri neredeyse sadece satıcının özellikle üstlendiği olasılıklarda uygulama alanı bulabilen bir sorumluluk rejimine dönüşecektir ${ }^{48}$. Zira zapt tehlikesinin bilinmediği ve bilmesinin gerekmediği hallerde çoğunlukla iyiniyetli kazanma gerçekleşecek, alıcının iyiniyetli sayılamadığı hallerde de zapt tehlikesinin "bilinmesinden" ötürü zapttan doğan sorumluluğa da başvurulamayacaktır. Bu bakımdan alıcının kast düzeyine varmayan ihmalinden kaynaklanan bilgisizliği halinde de satıcının zapt sorumluluğuna gidebilmesinin kabulü, yasada ayrıntılarıyla düzenlenmiş bu kurumun uygulama alanının koruması bakımından daha doğru olur.

Yasanın kabulü alıcının bilgisizliği olup alıcının bilgisi, satıcıyı sorumluluktan kurtaran bir itiraz olduğundan bu hususta ispat yükü satıcıya aittir ${ }^{49}$. Nitekim alıcıdan, zapt tehlikesinden haberdar olmadığını kanıtlamasını ve zapt sorumluluğunu tamamen bu hususun kanitlanmasına bağlamak beklenemez.

Yukarıdaki koşullar gerçekleştiği takdirde satıcının zapttan sorumluluğuna ilişkin olarak taahhütte ${ }^{50}$ bulunması, zapttan sorumluluğunun doğması için zorunludur. $\mathrm{Bu}$ üstlenmenin niteliği hakkında da açıklık yoktur. $\mathrm{Bu}$ nedenle satıcının, zapt halinden sorumlu olacağına ilişkin beyanının, ayıptan

46 Tunçomăg, s. 224; Öğretide buna örnek olarak alıcının kendine gönderilen tapu kaydı örneğini incelemekten çekinmesi örnek olarak verilmekte ise de bunun isabeti tartışmaya açıktır. Tapu sicilinin kamuya açıklığı karşısında, alıcı her durumda sicildeki kaydı bilmediğini ileri süremeyecektir (TMK m. 1020/III). BSK-Honsell, Art. 192 OR, N. 5; CR-Venturi/Zen-Ruffinen, Art. 192 CO, N. 6; Karş. BK-Giger, Art. 192 OR, N. 55, Yazar, genel olarak alıcının bilgisinin kanıtlama yükünün satıcıya ait olduğu görüşünde olup böyle hallerde de satıcının tapu sicilindeki kaydın varlığını kanıtlamasının yeterli olacağını savunmaktadır.

Aral/Ayrancı, s. 110; Gümüss, s. 55; BK-Giger, Art. 192 OR, N. 34 ve 54. Yarg. 13. HD., 21.3.1995, 1837/2797 (Kazanc1). Bu kararda zapt tehlikesinin bilindiği ve iyiniyetli olunmadığı ifade edilmiş olup Yargıtay'ın tutumu anlaşılmamaktadır. $\mathrm{Bu}$ yönde tespit ile zaptın açıç̧a garanti verilen durumlarda söz konusu olacağı şeklinde bkz. Hatemi/Serozan/Arpaci, s. 82.

49 BK-Giger, Art. 192 OR, N. 55; CHK-Hrubesch-Millauer, Art. 192 OR, N. 3; OFKKostkiewicz, Art. 192 OR, N. 10; ZK-Schönle/Higi, Art. 192 OR, N.46; Nomer/Engin, TBK m. 214, N. 38; Yarg. 13. HD., 3.12.2015, $28311 / 35520$ (Lexpera). 
sorumlulukta satıcının nitelik vaatlerinin hukuki niteliği hakkındaki tartışmayla ilişkilendirilmesi düşünülebilir. $\mathrm{Bu}$ bağlamda kanımızca, satıcının zaptın gerçekleşmeyeceğine dair beyanına sözleşmesel bir nitelik tanınmak ve alıcının güven kuramı çerçevesinde bu beyanı kabul ettiği şeklinde yorumlamak gerekir ${ }^{51}$. Bu üstlenmenin, sözleşme kurulduğu anda yapılması mümkün olduğu gibi sözleşme kurulduktan sonra tadil zımnında yapılması olanaklıdır. Ayrıca, eğer satıcının zaptın gerçekleşmeyeceğine ilişkin taahhüdü ${ }^{52}$ somut bir kişinin zapta girişmeyeceğine ilişkin ise, beyanın kabulü ile oluşan hukuki ilişkinin aynı zamanda üçüncü kişinin fiilinin taahhüt olduğu şeklinde de bir yorum yapılabilir. Bu durumda da zapt gerçekleşirse alıcı, diğer sözleşmesel hakları saklı kalmak üzere, TBK m. 128/I hükmüne dayanarak da istemde bulunabilir.

Zapt tehlikesinin alıcı tarafindan bilinmesinin, genel hükümlere başvurma olanağına etkisi de değerlendirilmek gerekir. Yukarıda değinildiği üzere tarafların bu durumu bilerek satış sözleşmesinin kurmalarının güven ilkesi çerçevesinde birtakım etkileri olabilir. Bu çerçevede, taraflar arasında örtülü bir sorumsuzluk anlaşması bulunduğu ve zapt tehlikesine ilişkin olarak genel hükümlere başvuru yolunun kapatıldığı sonucuna ulaşılabilir ${ }^{53}$. Zira alıcı, hangi hukuki temele dayanacağından bağımsız olarak, üzerinde üçüncü kişinin hak iddiasında bulunduğu bir eşyaya ilişkin sözleşme ilişkisine girmiştir. Bununla birlikte somut başka vakıalar, sözleşmenin zapt edilmeme şartına bağlı olarak kurulduğu sonucuna ulaşılmasını gerektirebilir $^{54}$. Ancak işlemlerin şarta bağlı olmaması asıl olduğundan, yorumda bu husus dikkate alınmalıdır ${ }^{55}$.

51 BSK-Honsell, Art. 197 OR, N. 16. Satıcının taahhütte bulunması halinde öncelikle sözleşmenin sonrasında tamamlayıcı olarak yasa hükümlerinin uygulanması şeklinde bu yönde yorumlanabilir görüş için bkz. Cavin, s. 66; Tandoğan, s. 155.

52 Ancak bu taahhüt, satılanı üstün haktan kurtarmak şeklinde de olabilir. Schumacher/ Rüegg, N. 98.

53 BK-Giger, Art. 192 OR, N. 58, Ancak Yazar İBK m. 97 (TBK m. 112)'den doğan talepten feragat edildiği şeklinde durumu açıklamaktadır. Yine yazara göre, alıcı satım bedelini önceden ödemiş ise bu durumda zapt gerçekleştiğinde İBK m. 119/II (TBK m. 136/II) uyarınca sebepsiz zenginleşme hükümleri çerçevesine bedelin iadesini talep edebilir.

54 BK-Giger, Art. 192 OR, N. 59; Sirmen, Lale: Türk Özel Hukukunda Şart, Ankara, 1992, s. 65.

55 BK-Giger, Art. 192 OR, N. 59. 


\subsection{Satılanın Teslim Edilmiş Olması}

Satıcının satılanı teslim etmiş olması zapttan sorumluluğun doğmasının koşullarından biridir" ${ }^{56}$ TBK m. 214 hükmünde yer alan "satılanın alıcının elinden alınırsa" ifadesi bu koşula örtülü olarak işaret etmektedir. Satılan alıcıya teslim edilmemiş ise, alıcı satıcının sorumluluğuna kural olarak borçlu temerrüdü nedeniyle gidebilecektir ${ }^{57}$. Satılanı teslim aldıktan sonra üçüncü kişinin hakkının tanınması sonucunda satılan alıcının hâkimiyetinden çıkmadıkça zapttan sorumluluk söz konusu olmayacaktır.

Alıcıya teslimden zilyetliğin herhangi bir şekilde geçirilmesinin mi anlaşılacağı yoksa fiili teslimin mi anlaşılması gerektiği akla gelebilir. Zapttan sorumluluğun satılanın zilyetlik ve mülkiyetini devretme borcunun uzantısı olduğu dikkate alındığında buradaki teslime, yasadaki genel kavramlarla da uyum sağlanmasını temin etmek için, TBK m. 207 ile aynı anlam verilmek gerekir ${ }^{58}$. Bu itibarla kural olarak satılanın fiilen teslimi gerekecek, ancak tarafların anlaşması ile zilyetliğin diğer devir yolları da bu kapsamda kabul edilebilecektir.

\subsection{Satılan Üzerinde Üçüncü Kişinin Sözleşme Kurulduğu Anda Üstün Hakka Sahip Olması}

Zapttan sorumluluk, üçüncü kişinin üstün hakkının bulunmasına daya$1 ı d ı r^{59}$. Bu durumda alıcı, iyiniyetle kazanım yahut kazandırıcı zamanaşımı

56 CR-Venturi/Zen-Ruffinen, Art. 192 CO, N. 4; ZK-Schönle/Higi, Art. 192 OR, N. 40; Huguenin, N. 2563; Tandoğan, s. 151; Tunçomağ, s. 211;Feyzioğlu, s. 252; Yavuz, s. 112; Aral/Ayrancı, s. 109; Zevkliler/Gökyayla, s. 142; Eren, N. 241; Gümüş, s. 55; Doğu, s. 521; Engel, 28; Dolaysız zilyetliğin devri: Nomer/Engin, TBK m. 214, N. 42; Zilyetliğin devri şeklinde: Hatemi/Serozan/Arpacı, s. 83; Cavin, s. 65; BSK-Honsell, Art. 192 OR, N. 4; Tercier/Venturi, N. 319; Schmid, s. 357; Taşınmaz satışlarında ise alıcı adına tescil yapılması gerekir: Schumacher/Rüegg, N. 92. Bkz ve karş.: Çabri, s. 592-593. Dikkat etmek gerekir ki zaptın gerçekleşebilmesi için, şerh ile doğmayan eşyaya bağlı borçlar hariç olmak üzere, alıcı adına yapılan tescilin gerçek hak durumunu yansıtmaması, başka bir deyişle yolsuz olması lazım gelir.

57 Kılıçoğlu, s. 66; TBK m. 112 vd. şeklinde: Yavuz, s. 112; Bucher, s. 89; BK-Giger, Art. 192 OR, N. 38; Eren, N. 241; Türker, s. 80.

58 Öğretide genel kabul alıcının teslim harici zilyetliğin nakli çeşitlerini kabul etmeye zorlanamayacağı bu bakımdan 818 sayılı ile yürürlükteki Borçlar Kanunu arasında bir farklılığın kabul edilmemesi gerektiği şeklindedir: Nomer/Engin, TBK m. 210, N. 2; Gümüş, s. 50-51; Yavuz, s. 89; Atamer, s. 190; Aksi yönde: Öz, Turgut: Yeni Borçlar Kanununun Getirdiği Başlıca Değişiklikler ve Yenilikler, İstanbul, 2011, s. 27, ancak yazar sadece dolaylı zilyetliğin devri bakımından hükmün ifayı kabul etmesini eleştirmektedir. Zilyetliğin devrinin yeterli gören görüş: Kılıçoğlu, s. 66. 
hükümleri çerçevesinde, satılanı iktisap edebildiği hallerde zapttan sorumluluk söz konusu olmaz ${ }^{60}$. Dolayısıyla yasanın bu ayrık kazanma şekillerine tanıdığ alan ölçüsünde zapttan sorumluluk kuramsal temelini muhafaza etmiş olsa da uygulama alanı daralmış bir sorumluluk rejimidir ${ }^{61}$. Bu itibarla alıcının, tasarruf yetkisine sahip olmayan satıcıdan satılanı iyiniyetle kazanım hükümleri çerçevesinde iktisap edip etmediği incelenmek gerekir. Zaptın uygulama alanı bulabileceği hallere örnek olarak, alıcının kötüniyetli sayılması nedeniyle satılanı iktisap edememiş olması, çalıntı eşyaların $\operatorname{satış}^{62}$, iyiniyetli kazanmaya yasanın olanak tanımadığı hakların satışı verilebilirr ${ }^{63}$.

\subsubsection{Zapttan Sorumluluğu Doğurmaya Elverişli Üstün Haklar}

\subsubsection{Mutlak Haklar}

Üçüncü kişinin, satıcının zapt sorumluluğunu doğuracak şekilde ileri süreceği satılan üzerinde sahip olduğu üstün hakkı, en başta, mutlak hak olabilir $^{64}$. Satılan eşya üzerinde mülkiyet yahut sınırlı ayni hakların ${ }^{65}$ bulun-

60

Schmid, s. 358.

Tandoğan, s. 150; Eren, N. 233; Gümüş, s. 54; Acar, s. 107; Cavin, s. 63-65; CRVenturi/Zen-Ruffinen, Intro. Art. 192-196a CO, N. 2; Tercier/Venturi, N. 315; Uygulama alanını neredeyse tamamen kaybettiği şeklinde bkz. Hatemi/Serozan/ Arpaci, s. 82.

62

BK-Giger, Art. 192 OR, N. 32; ZK-Schönle/Higi, Art. 192 OR, N. 2a.

BSK-Honsell, Art. 192 OR, N. 3; CR-Venturi/Zen-Ruffinen, Intro. Art. 192-196a CO, N. 3; Schmid, s. 359-360; Hatemi/Serozan/Arpacı, s. 81-82; Tunçomăg, s. 210; Eren, N. 234 vd.; Aral/Ayrancı, s. 108; Tandoğan, s. 150-151; Cavin, s. 64; JdT 1986 I 326; Çifte tapu halinde iyiniyetle kazanım korunmadığından, bu durumda gerçek hak sahibi tarafından taşınmazın zilyetliği elden alındığında zapt hükümleri uygulama alanı bulur: Yarg. 13. HD., 26.1.2011, 10519/897 (Kazanc1); TMK m. 862/III uyarınca eklentilere ilişkin olarak rehin söz konusu olduğunda iyiniyetle edinimin istisna tutulduğu kabul edilirse (Bu konuda ayrıntılı bilgi: Günel, M. Cahit: Taşınmaz Rehninin Kapsamı Çerçevesinde Eklentinin Hukuki Durumu, İstanbul, 2013, s. 58-59), bu eklentiler açısından zapt hükümleri uygulanabilecektir. Bkz. Cavin, s. 64.

64

Zevkliler/Gökyayla, s. 142; Gümüş, s. 54-55; BSK-Honsell, Art. 192 OR, N. 2; Zapttan sorumluluğun salt ayni haklar açısından söz konusu olabileceği görüşü: Kılıçoğlu, s. 66; İBK m. 259/II, 260 istinası ile: Bucher, s. 88; Alacağın ivaz karşılı̆̆ devri halinde de zapta ilişkin hükümlerin uygulanabileceği görüşünde: Eren, N. 237; Huguenin, N. 2556; CR-Venturi/Zen-Ruffinen, Intro. Art. 192-196a CO, N. 3; Pekmez, s. 525; OFK-Kostkiewicz, Art. 192 OR, N. 3. Bununla birlikte alacağın devrinde öngörülmüş garanti sorumluluğu, satış sözleşmesindeki zapta karşı tekeffül hükümlerine gitmeye gerek bırakmaz, alacağın varlığını tekeffül alacağın intifa veya rehin hakkıyla kayıtlı olmamasını da kapsar. Bu yönde: Hatemi/Serozan/Arpacı, s. 85- 
mas1 bu kapsama girer ${ }^{66}$. Keza devre konu bir fikri hak ${ }^{67}$ ise, bu hakkın da rehin gibi bir özdeş hakla sınırlanmış olması zapttan doğan sorumluluğun uygulanmasına neden olabilir ${ }^{68}$. Ancak satım konusu üzerinde, devri amaçlanan hak ile özdeş olmayan bir başka mutlak hak ileri sürülüyorsa bu durumda kanımızca zapt söz konusu olmaz ${ }^{69}$, hukuki ayıp hükümleri uygulanmak gerekir. Örnek olarak satılan, patent veya marka ihlali nedeniyle piyasaya sürülemiyorsa ya da TTK $\mathrm{m}$. 56/IV uyarınca haksız rekabete konu olmuş ve haklarında TTK m. 56/I b ve c bentleri uyarınca hüküm verilmiş olan eşyanın satışı hallerinde, hukuki ayıp söz konusu olacaktır ${ }^{70}$. Zira sözleşmeye konu malvarlığı unsurunun alıcıya devredilmiş olması hususu bakımından engel yoktur ${ }^{71}$. Bu bakımdan fikri haklar ${ }^{72}$ bakımından ayrım, söz-

86; Acar, s. 108; Koller, §1 N. 13; ZK-Schönle/Higi, Art. 192 OR, N. 30; Cavin, s. 62; Bucher, s. 84; ATF 110 II 239.

Alacak satışı söz konusu ise, mutlak bir hak niteliğinde olmasa da satış konusu ile özdeş olduklarından alacağın intifa hakkı veya rehinle sınırlanmış olması da bu kapsamda değerlendirilmek gerekir.

66 Satış sözleşmesinin kurulduğu anda derdest bir kadastro davasında verilen karar sonucunda taşınmazın üçüncü kişi adına tescil edilmesi hali örnek olarak verilebilir: Yarg. 13. HD., 11.10.2004, 4841/14134 (Kazanc1). Mülkiyet hakkının varlığı halinde tam zapt, sınırlı ayni hakların ve bu arada rehin haklarının varlığı halinde ise kısmı zapt söz konusu olacaktır. Bkz. CR-Venturi/Zen-Ruffinen, Art. 192 CO, N. 5; Schmid, s. 356; ZK-Schönle/Higi, Art. 192 OR, N. 37; Eren, N. 239. Rehin hakkının varlığı doğrudan doğruya satılanın alıcının elinden alınmasına yol açmasa da paraya çevrilme ihtimalinin bulunması ve alıcının satılandan yararlanma olanağını sınırlaması zapt hükümlerinin uygulanmasını doğrulamaktadır. Rehinli satılan paraya çevrilirse, tam zaptın söz konusu olacağı: Pekmez, Cüneyt: "Satış Sözleşmesinde Zaptın Hukuki Sonuçları", Türkiye Adalet Akademisi Dergisi, Y1l: 6 S. 20 (Ocak 2015), s. 524 dn. 1. Paylı mülkiyet veya elbirliği mülkiyetinin söz konusu olmasında da kısmi zapt gerçekleşmiş olur: JdT 1975 I 67.

$\mathrm{Bu}$ durumda taşınır satışına ilişkin hükümlerin TBK m. 209 uyarınca uygulanacağı: Yavuz, s. 84; Gümüş, s. 17; Tandoğan, s. 102.

68 Patent, faydalı model, eser sahipliğinden doğan haklarının devrinde zaptın söz konusu olabileceği hakkında bkz. BSK-Honsell, Art. 192 OR, N. 2; Alacağın devrine kıyasen: BK-Giger, Art. 192 OR, N. 35; Genel olarak: CR-Venturi/Zen-Ruffinen, Intro. Art. 192-196a CO, N: 3; Satış konusu olabilen mutlak hakların zapta imkân tanıyabileceği hakkında bkz. Gümüşs, s. 55. BK-Giger, Art. 192 OR, N. 23-24, Yazar her halde fikri hakların zapta yol açacağı görüşünü savunmaktadır.

70 Tandoğan, s. 169-170; Patent ihlali ile üretilmiş bir eşyada zaptın değil hukuki ayıbın söz konusu olacağı hakkında: ATF 82 II 239.

71 Cavin, s. 77.

72 Elektronik kitaplara ilişkin sözleşmelerde zapta ilişkin sorumluluğun uygulanabileceği: Eggen, Mirjam: “eBook - myBook oder yourBook?”, recht 2017, s. 122 vd. 
leşmenin ilgili fikri hakkı konu edinip edinmemesine göre yapılmalıdır. Örnek olarak, eser sahipliğinden doğan bir mali hakkın devrinde, söz konusu hak daha önceden rehnedilmişse kısmi zapt söz konusu olurken, satıcının toptancıdan satın aldığı ürünlerin satışı, ürünün üzerinde başkasına ait bir eserin bulunmasından ötürü mümkün olmuyorsa hukuki ayıp ${ }^{73}$ söz konusu olmalıdır.

\subsubsection{2. Şerh Edilmiş Nisbi Haklar}

Şerh edilmiş kişisel hakların da zapt hükümlerinin uygulanmasına neden olması mümkündür ${ }^{74}$. Böylece, mesela şerh edilmiş bir alım hakkının alıcıya karşı kullanılması halinde, alıcının alım hakkı sahibine karşı taşınmazı devretmekten kaçınamayacağı için satıcının zapttan sorumluluğu doğacaktır. Gerçekten de sonuç olarak bu durumda da satılan, her ne kadar ilgililer arasında borç ilişkisi bulunsa da kaynağında şerhin eşyaya bağlı borç etkisi bulunduğu için alıcının elinden iradesine bakılmaksızın çıkmaktadır. Bununla birlikte, bu olasılığın gerçekleşmesinin zayıf olduğu ifade edilmek gerekir. Zira tapu siciline şerh ile doğan etki sicilin kamuya açıklı̆̆ 1 sonucunda, satıcıya TBK m. 214/II'ye dayanma olanağ1 verir. Bu durumda sat1cının açık taahhüdü olmadıkça, zapttan sorumluluk doğmaz ${ }^{75}$. Eğer şerh yolsuz olarak terkin edilmiş ise, bu sefer iyiniyetle kazanım (TMK m. 1023) sonucunda alıcıya karşı şerh edilmiş hakkın ileri sürülmesi söz konusu olamaz. Ancak alıcı kötüniyetli ise, müspet vukuf varsa satıcının açık taahhüdü olması kaydıyla, şerh edilen hak alıcıya karşı ileri sürülebilir ve zapttan sorumluluk doğabilir.

\subsubsection{3. Şerhin Etkisiyle Doğmayan Eşyaya Bağlı Borçlar}

Eşyaya bağlı olan ve satılanın alıcının elinden alınmasına yol açabilecek nitelikteki borçlar da zapttan sorumluluk hükümlerinin uygulanmasına elverişlidir. Zira sonuçları itibarıyla şerh edilmiş nisbi haklara benzeşirler. Nitekim belirtildiği üzere nisbi hakların şerh edilmesinin eşyaya bağlı borç etkisi bulunmaktadır ${ }^{76}$. Sonuç olarak ayrım yapılmasını gerektirecek bir nitelik farkı söz konusu değildir. Bu çerçevede, TMK m. 725/II uyarınca

73

74 Nomer/Engin, TBK m. 214, N. 34; Aydoğdu/Kahveci, s. 122; Zevkliler/Gökyayla, s. 142; Feyzioğlu, s. 252; Eren, N. 239; CR-Venturi/Zen-Ruffinen, Art. 192 CO, N. 5; BSK-Honsell, Art. 192 OR, N. 2; Çabri, s. 594.

75 Çabri, s. 588 ve 596.

76 Genel olarak eşyaya bağlı borçların zapta sebebiyet verebileceği: Koller, §4 N. 71; ZKSchönle/Higi, Art. 192 OR, N. 44. 
arazisine taşan kısma ${ }^{77}$ ilişkin olarak mülkiyetin devri yahut irtifak hakk1 kurulması, zorunlu geçit hakkı istemine veya eşyaya bağlı oldukları kabul edildiği ölçüde kanundan doğan ipotek hakkı tesisi istemine ${ }^{78}$ muhatap olan alıcı, satıcının kısmi zapttan doğan sorumluluğuna gidebilecektir ${ }^{79}$.

Anılan durumlar haricinde, alıcıya satılan üzerinde üçüncü kişiler nisbi haklarını ileri sürülemez ${ }^{80}$. İstisnai olarak satıcı kendisine karşı yöneltilen bir talep hakkına karşı, kanundan veya şerhten kaynaklanan eşyaya bağlı borç nedeniyle savunma imkânına sahip olmayabilir. Bunun dışında ilgili borç ilişkisine satılan üzerinde hak sahibi olan kişi kanun gereği ${ }^{81}$ taraf kılınmış ise de, alıcı kendisine karşı yöneltilen nisbi haktan doğan talebi bertaraf edemez. TBK m. 310 uyarınca, satılan kiralanmış ise alıcı kira sözleşme$\operatorname{sinin}^{82}$ tarafı olur ve kira sözleşmesinden doğan haklar malik alıcıya karşı kiracı tarafından ileri sürülebilir. Bu hallerde de kısmi zapt söz konusu olur $^{83}$. Zira bu durumunda alıcının hukuki pozisyonu, eşyaya bağlı borç-

77 Oğuzman, M. Kemal/Seliçi, Özer/Oktay-Özdemir, Saibe: Eşya Hukuku, İstanbul, 2018, N. 1849 dn. 1028 ve N. 1869; Yarg. 1. HD., 24.9.2004, 6856/9891 (İstanbul Barosu Dergisi 2005/2, s. 498); JdT 1973 I 370; Serozan, Rona: "Komşunun Arsasına Taşan Yapı", İstanbul Üniversitesi Hukuk Fakültesi Mecmuası, C. 42 S. 1-4 (1976), s. 269-270; Akman, Sermet: Taşkın İnşaat, İstanbul, 1982, s. 184 Atlı, Banu: "Taşkın Yapıya Katlanma Yükümlülüğünün Oluşma Koşulları”, Dokuz Eylül Üniversitesi Hukuk Fakültesi Dergisi, C. 19 (Özel Sayı: Prof. Dr. Şeref Ertaş’a Armağan-2017), s. 995; Ercoşkun Şenol, H. Kübra: "Hem Haksız Hem de Taşkın Yapı Niteliğindeki Yapılar", Türkiye Adalet Akademisi Dergisi Y1l: 11 S. 38 (Nisan 2019), s. 39. Aksi yönde: Yarg. 14. HD., 15.11.2005, 7378/9865 (Kazanc1). Haksız yapıya ilişkin mülkiyetin malzeme sahibine geçirilmesi talep hakkının yükümlüsü açısından eşyaya bağlı olmadığı hususunda: Oğuzman/Seliçi/Oktay-Özdemir, N. 1775.

78 Rüegg, §5 N. 27; Yapı alacaklısı ipoteği bakımından zapt uygulanabileceği şeklinde: Schmid, s. 356 ve 359. İpotek tesis edildiği anda satış sözleşmesinin kurulmasından sonra doğmuş bir hak olacağı fikriyle aksi yönde: Kuonen, Nicolas: "Les relations entre les intervenants dans la construction”, Journees suisse du droit de la construction 2011, 2010, Institut für Schweizerisches und Internationales Baurecht, s. 18.

79 Benzer şekilde: Huguenin, N. 2559.

80 Aydoğdu/Kahveci, s. 122; Zevkliler/Gökyayla, s. 142.

81 Bunun dışında nisbi haklar herhangi bir şekilde zapta yol açmaz. JdT 1973 I 370’te, taşınmaz üzerinde üçüncü kişinin arazinin eski maliki ile arasındaki anlaşma uyarınca yaptığı yolun zapta yol açmayacağı, ancak ayıp olarak nitelendirilebileceği belirtilmiştir. Engel, s. 29.

82 Kira sözleşmesi şerh edilmiş ise alıcı, durumu biliyor farz edildiğinden kural olarak zapttan sorumluluk doğmaz. Schmid, s. 358.

83 ZK-Schönle/Higi, Art. 192, N. 37, 44; Schmid, s. 356-357; Özen, Burak: "Kira Konusunun Devri", Bahçeşehir Üniversitesi Hukuk Fakültesi Dergisi, C. 9 S. 103-104 (2013), s. 102-103. Aksi yönde bkz. BSK-Honsell, Art. 192 OR, N. 2; Tandoğan, s. 
lardan farklılık arz etmemektedir. Eş söyleyişle, alıcının ileri sürülen hakka karşı savunma olanağının bulunup bulunmamasına göre üstün haklar belirlenmek gerekir.

\subsubsection{Satılanın Haczedilmiş Olması}

Haciz, icra hukukuna ait bir kavramdır. Maddi hukuktaki haklar kategorileri içinde yer almamaktadır. Ancak, salt özel hukuk kaynaklı olmadığı gerekçesiyle satılanın haczedilmiş olduğu hallerde, alacaklının satılanı icra yoluyla paraya çevirmeye girişmesinin zapttan sorumluluğu doğurmayacağ1 kabul edilemez ${ }^{84}$. Zira haciz, alacağa bağlıdır ve talep hakkının uzantısını oluşturur ${ }^{85}$. Böylece haciz ile alacaklı, alacağına bağlı olarak rehin benzeri şekilde haczedileni paraya çevirme olanağ 1 kazanır ${ }^{86}$. Başka bir deyişle haciz, alacaklı lehine bir işlem ${ }^{87}$ olup onun alacak hakkını kuvvetlendirir, esasında onun sonucu ve uzantısıdır. Takip hukukundan kaynaklı da olsa bir hak söz konusudur. Salt icra takibi içinde haczin gerçekleşmesi burada kamu hukukuna dayalı bir talebin olduğunu kabule yeterli olmaz. Bu nedenle satılanın haczedilmiş olması hukuki ayıp olarak nitelendirilemez ${ }^{88}$. Keza

152; Zevkliler/Gökyayla, s. 142; Eren, N. 244; CR-Venturi/Zen-Ruffinen, Art. 192 CO, N. 5; Tercier/Venturi, N. 321.

Karş. Hukuki ayıp yönünde: Zevkliler/Gökyayla, s. 117.

Oğuzman, M. Kemal/Öz, Turgut: Borçlar Hukuku Genel Hükümler, C. I, İstanbul, 2018, N. 52-53; Eren, Fikret: Borçlar Hukuku Genel Hükümler, Ankara, 2019, N. 225; Özmen, E. Saba: "Türk Hukukunda Hacizlerin Şerhle Kazandığı Hukuki Nitelik ve Buna Bağlı Hukuki Sonuçların İrdelenmesi”, Ankara Barosu Dergisi, 1991, S. 2, s. 184; Alacaklının haczettirme hakkının kamu hukukundan doğan bir hak olduğu: Tercier, Pierre/Pichonnaz, Pascal/Develioğlu, H. Murat: Borçlar Hukuku Genel Hükümler, İstanbul, 2016, N. 127 ve 131. Haciz halinde zaptın nisbi hakka dayalı olarak gerçekleşmiş olduğu: Nomer/Engin, TBK m. 214, N. 34.

Kuru, Baki: İcra ve İflas Hukuku El Kitab1, Ankara, 2013, s.457. Haciz ile takip hukukundan kaynaklanan bir hakkın doğduğuna ilişkin olarak bkz. Pekcanıtez, Hakan/ Atalay, Oğuz/Sungurtekin-Özkan, Meral/Özekes, Muhammet: İcra ve İflâs Hukuku, Ankara, 2012, s. 309; Kuru, s. 457; Benzer yönde: Postacioğlu, İlhan/Altay, Sümer: İcra Hukuku Esasları, İstanbul, 2010, N. 283.

Özmen, s. 183.

Zaptın gerçekleşeceği yönünde: Yarg. 13. HD., 20.3.1995, 2191/2694 (Kazanc1); Yarg. HGK., 3.5.1995, 15-255/511 (Kazanc1). Hukuki ayıp yönünde: Yarg. HGK., 20.6.2019, 1657/744 (Lexpera); Yarg. 19. HD., 18.3.2013, 13737/4704 (Lexpera); Yarg. 13. HD., 19.3.2009, 13076/3661 (Kazanc1); Yarg. 13. HD., 22.10.2001, 7856/9445 (Kazanc1). Karş. Yarg. 19. HD., 30.5.2011, $11839 / 7179$ (Lexpera): “...Satım akdinde alıcının zapta karş1 tekeffül hükümlerine dayanabilmesi için aracın hukuken ayıplı olduğunu ispat etmesi gerekir."; Yarg. 13. HD., 20.12.2011, 13524/19637 (Kazanc1): "Taraflar arasındaki uyuşmazlık geçerli satıştan kaynaklanan BK. 189 ve sonraki maddelerinde düzen- 
haczedilmiş malvarlığı unsuru üzerinde borçlandırıcı işlem yapmaya sınırlama getirmediği gibi sadece tasarruf yetkisine kayıtlama getirir ${ }^{89}$. Bu nedenle haczedilmiş malvarlığı unsurlarına ilişkin satış sözleşmeleri TBK m. 27'ye aykırı değildir.

Haciz ile satılan üzerinde tasarruf yetkisi kısıtlanır, taşınırlara ilişkin olarak IIIK m. 86 bu hususu açıkça hükme bağlamaktadır. Yine aynı hüküm üçüncü kişilerin iyiniyetle kazandığı hakları saklı tutarak, zapt hükümlerinin uygulanmasını bertaraf etmektedir. Haczi bilen veya bilmesi gereken kişiler bakımından ise İIK m. 86/III, tasarruf işlemlerinin alacaklının haklarını ihlal ettiği ölçüde hükümsüz olduğunu (nisbi etkisizlik) belirtmektedir ${ }^{90}$. Dolay1sıyla, alacaklı takipten doğan alacağını tahsil etmek için kötüniyetli alıcının elindeki satılanı, paraya çevirebilir. Bu durumda da kötüniyetli alıcı bakımından satıcının zapttan doğan sorumluluğuna gitme olanağ doğar.

Taşınmazlarda ise haciz işlemiyle birlikte İİK m. 91 hükmü uygulama alanı bulur ve taşınmaza ilişkin tasarruf yetkisi kısıtlanır ${ }^{91}$. Haczin şerh edilmesiyle TMK m. 1010/I b. 2 uyarınca taşınmaz üzerinde sonradan mutlak hak kazananlar, taşınmazın paraya çevrilmesine katlanmak zorunda kalır ${ }^{92}$. $\mathrm{Bu}$ durumda tapu sicilinin açıklığı gereği satıcının ancak özel taahhüdü ile zapttan sorumlu olması söz konusu olabilecektir.

\subsection{2. Üstün Hakkın Sözleşme Kurulduğu Anda Var Olması}

Türk Borçlar Kanunu m. 214'ün açık düzenlemesinden anlaşıldığ üzere, zapttan sorumluluğun söz konusu olabilmesi için üstün hakkın en geç satış sözleşmesinin kurulduğu anda var olmas $1^{93}$ gereklidir $^{94}$. Üçüncü kişinin

lenen zapta karşı tekeffül hükümlerinden kaynaklanmıştır. Davalı N.'ye ait aracın geçerli sözleşme ile davacı H.'ye satıldığı ve aracın hukuki ayıplı olması sebebiyle zaptedildiği uyuşmazlık dışıdır.".

89 Pekcanıtez/Atalay/Sungurtekin-Özkan/Özekes, s. 309; Postacioğlu/Altay, N. 304; Nomer/Engin, TBK m. 214, N. 23.

90 Kuru, s. 432-433; Postacioğlu/Altay, N. 301.

91 Özmen, s. 193; Pekcanıtez/Atalay/Sungurtekin-Özkan/Özekes, s. 309; Kuru, s. 444

92 Doğan, Murat: Tapu Sicilinde Tasarruf Yetkisi Kısıtlaması Şerhi, Ankara, 2004, s. 63.

93 Üçüncü kişinin üstün hakkının beklenen hak halinde olmasının yeterli olup olmayacağı sorunu akla gelebilir. TBK m. 171/III hükmü çerçevesinde beklenen hakka tanınan koruma dikkate alındığında, beklentinin sözleşme kurulduktan sonra gerçekleşmesi halinde satıcının zapttan sorumluluğuna gidilebilmesi olanaklı sayılabilir. Beklentiye konu hakkın "üstün" olması yeterlidir. Zira beklenti, tam hakka benzer şekilde hukuki koruma görebilmektedir. Beklentinin hukuki niteliği hakkında bkz. Nomer, s. 143-146; İlgili hakkın satış sözleşmesinin kurulduğu andaki varlığı çekişmeli ise alıcı ile satıcı arasındaki davada bu hususun geçmişe etkili olarak hükme bağlanacağına ilişkin olarak: 
üstün hakk1, satış sözleşmesinin kurulmasından sonra doğmuş ise alıcı satıcının sorumluluğuna ancak genel hükümler ${ }^{95}$ uyarınca gidebilir.

BK-Giger, Art. 192 OR, N. 42. Ancak bu davadaki tespit, taraf olmayan üçüncü kişi üstün hak sahibini etkilemeyecektir.

Tandoğan, s. 153; Tunçomağ, s. 214; Yavuz, s. 112; Aral/Ayrancı, s. 110; Zevkliler/ Gökyayla, s. 142; Hatemi/Serozan/Arpacı, s. 82; Gümüş, s. 55; Engel, s. 29; BSKHonsell, Art. 192 OR, N. 4; BK-Giger, Art. 192 OR, N. 41; Feyzioğlu, s. 252; Örnek olarak, satılan üzerinde, satış sözleşmesinin kurulmasından sonra satıcının borcu nedeniyle haciz uygulanır ve bunun sonunca alıcının elinden çıkarsa zapt hükümleri uygulama alanı bulmayacaktır. Bkz. Yarg. 13. HD., 23.5.2003, 990/6426 (Kazanc1); Nomer/ Engin, TBK m. 214, N. 23.

95 TBK m. 112 vd. şeklinde bkz. Yavuz, s. 112; Gümüş, s. 56; Eren, N. 245; Türker, s. 86; BK-Giger, Art. 192 OR, N. 43; Huguenin, N. 2560; Satıcının sorumluğuna borçlu temerrüdü hükümleri uyarınca gidilebilmelidir. Zira satılan üzerinde üçüncü kişinin üstün hakkı bulunsa da edimin ifası objektif olarak imkânsız değildir. Eğer bu durum imkânsızlığa sebebiyet verse idi, üstün hakkın sözleşme kurulduğu an mevcut olmas1 gerekçesiyle, başkasının eşyasının satışı TBK m. 27 uyarınca hükümsüz olmak gerekirdi (ZK-Schönle/Higi, Art. 192 OR, N. 7, yazarlar burada sürekli sübjektif imkânsızlığın söz konusu olduğunu belirtmektedir.). Böyle bir halde imkânsızlık ancak üçüncü kişinin satılanın devrine dair rızasının alınamayacak olmasının anlaşılması halinde söz konusu olabilir. Çünkü borçluya satıcıya karşı verilecek aynen ifa hükmünün bu halde bir icra kabiliyeti olmaz. Bkz. ve Karş. Hatemi/Serozan/Arpacı, s. 79. Yarg1 kararlarında da bir eşyanın mülkiyetinin sonradan üçüncü kişiye aktarılmış olması durumu edimin imkânsızlaşması olarak nitelendirilmekte ama bu konuda belirtilen hususa değinilmemektedir. Bkz. Yarg. 3. HD., 5.2.2013, 18832/1562 (Kazanc1); Yarg. 13. HD., 23.12.1980, 6420/ 7063 (Kazanc1); Yarg. HGK., 29.9.2000, 14-386/427 (Kazanc1); İmkansılılı üçüncü kişinin devre rıza göstermeyeceğinin anlaşılmasıyla gerçekleşebilir. $\mathrm{O}$ andan önce ancak TBK m. 125/II uyarınca olumlu zararının tazminini talep edebilir. Karş. BK-Giger, Art. 192 OR, N. 10, Yazar zapt ile temerrüt hükümlerinin yarışması bağlamında temerrüde, alıcının satıcının ifa etmesinin beklemenin boşuna olmadığını kanıtlaması halinde başvurulabileceğini belirtmektedir. İsviçre Federal Mahkemesi de devir borçlusunun, tasarruf yetkisini kaybetmesi sonucunda sübjektif imkânsızlığın gerçekleşeceğini ancak ilgilinin rızasının alabileceği veya tasarruf yetkisini tekrar kazanabileceği hallerin istisna olduğunu belirtmiştir. Bkz. JdT 2011 II 529 “ Ticaret hayatındaki iyi niyet ilkeleri uyarınca, borçlundan ifa talep edilmesi olanaksız hale geldiğinde, edim sübjektif olarak imkânsızdır. ...Borçlu bakımından ifa engeli tamamıyla aşılamaz olmalıdır. Federal Mahkemenin içtihadına göre borçlunun tasarruf yetkisinin sonradan kaybetmesi aşılamaz bir engel olabilir. Sinırlayıcı olarak belirtilmelidir ki borçlunun tasarruf yetkisini geri kazanma veya bu yetkiye sahip kişilerin rızasını edinme olanağının bulunması halinde, ifa engeli borçlu bakımdan aşılamaz değildir. "; Karş. ATF 84 II 6, Bu kararda davalının tasarruf yetkisinin bulunmaması objektif bir imkânsızlık sebebi sayılmış ancak imkânsızlıktan kusuruyla sorumlu olduğu belirtilmiştir. Tekrar ifade etmek gerekir ki tam zapt halinde sözleşme ilişkisi tasfiye sürecine gireceğinden satıcının borçlu temerrüdü nedeniyle sorumluluğuna gidilemez. 


\subsection{Zaptın Gerçekleşmesi}

Zapttan sorumluluğun doğabilmesi için, üçüncü kişinin yukarıda değinilen üstün hakkını alıcıya karşı ileri sürmesi ve bunun sonucunda hakkın yarg1 kararı ${ }^{96}$ ile veya iradi olarak tanınmak suretiyle satılanın alıcının elinden çıkması gerekir ${ }^{97}$. Tek başına alıcının satılan üzerinde mülkiyeti kazanmamış olması satıcının zapttan sorumlu tutulması sonucunu doğurmaz ${ }^{98}$. Bu, bir bakıma, Roma hukukundan gelen satıcının rahat zilyetliği sağlama borcunun bulunması fakat mülkiyeti devir borcunun bulunmamasının ${ }^{99}$ kalınt1sidir.

TBK m. 216/II açık düzenlemesi ile de yürürlükten kalkan Borçlar Kanunu döneminden farklı olarak üçüncü kişinin üstün hak iddiasının mahkeme dışında da ileri sürülüp tanınabileceği tartışmadan uzak biçimde

96 Salt kolluğa şikâyetin yeterli olmayacağı, bu durumda üçüncü kişinin üstün hakkının kanıtlanmasının zorunlu olduğu görüşünde: Yarg. 13. HD., 29.1.1986, 7858/427 (Kazancı). Karş. İrade açıklamasının yeterli olabileceği: Huguenin, N. 2566; Gümüş, s. 56; Aral/Ayrancl, s. 110.

97 CR-Venturi/Zen-Ruffinen, Art. 192 CO, N. 5; Koller, §4 N. 78; Tunçomağ, s. 212; Gümüş, s. 56-57; Zevkliler/Gökyayla, s. 143; Doğu, s. 522; Eren, N. 243, yazar def'i yoluyla hakkın ileri sürülmesini zaptın gerçekleşmesi için yeterli saymaktadır. Karş. Alıcının elinden eylemli olarak çıkmanın dışında, alıcının satılanı elinde tutmak için başkaca yükümlülükleri yerine getirmesinin gerekli olmasının da zapta yol açacağı: OFK-Kostkiewicz, Art. 192 OR, N. 6; Nomer/Engin, TBK m. 214, N. 48; Bu durumlarda örnekseme ile uygulanacağı: CR-Venturi/Zen-Ruffinen, Intro. Art. 192-196a CO, N. 4; ZK-Schönle/Higi, Art. 192 OR, N. 41. Ayrıca, satış bedelinin alıcıya TMK m. 989/II uyarınca ödenmiş olmasının zaptın gerçekleşmesine engel olmadığı: Türker, s. 42; Acar, s. 108; Yarg. 19 HD., 17.12.2015, 5116/17088 (Lexpera) “...zapta karş1 tekeffül hükümlerinin uygulanabilmesi için satılanın tamamı veya bir kısmının alıcının elinden alınması gerekir. Oysa dava konusu aracın halen davacının elinde olduğu anlaşılmaktadır.".

ZK-Schönle/Higi, Art. 192 OR, N. 39; Genel hükümlere başvurulması mümkündür. Huguenin, N. 2567; İptal hakkına başvurulabileceği: Koller, §4 N. 78; JdT 1984 I 388; JdT 1984 I 139. Tam zapt gerçekleştikten sonra sözleşme dahi sözleşmesel ilişki sona ermeye yönelik olsa dahi devam ettiğinden iptal yoluna gidilmesi kural olarak mümkün olmalıdır: ZK-Schönle/Higi, Art. 192 OR, N. 23.

99 Zimmermann, Reinhard: The Law of Obligations - Roman Foundations of the Civilian Tradition, Cape, 1992, s. 293-294; BK-Giger, Art. 192 OR, N. 12; Bucher, s. 89; Hatemi/Serozan/Arpacı, s. 80; Ayrıca: Yüksel, Halil İbrahim: Roma Hukukunda satış sözleşmesi (Emptio-venditio), İÜSBE Yüksek Lisans Tezi, İstanbul, 2015, s. 93 vd. Hukukumuzda mülkiyeti ve zilyetliği devir borcunun açıkça bulunması karşısında özel olarak zapttan sorumluluğun düzenlenmesi zorunlu değildir. Bkz. Cavin, s. 62 vd.; Engel, s. 28; Nomer/Engin, TBK m. 214, N. 2. Karş. Yavuz, s. 109. 
hüküm altına almıştır ${ }^{100}$. Kaynak İsviçre kanunundan farklı olarak ilgili fikranın bulunmadığ 1 yürürlükten kalkan Borçlar Kanunu döneminde bir görüş ancak üstün hakkın dava yolu ile ileri sürüldüğü takdirde tanınabileceği şeklindeydi ${ }^{101}$. Bu kabul ise hem kaynak kanuna aykırı bir yoruma yol açmakta ve hem de gereksiz yere yargılama yapılmasına yol açmaya elverişliydi ${ }^{102}$.

Satılan, üçüncü kişinin şikâyetçi olduğu ceza soruşturması veya kovuşturması sonucunda, alıcının elinden almış ise, yine bu durumda da şikâyetçi olmak hakkın ileri sürülmesi şeklinde yorumlanmalıdır ${ }^{103}$. Nitekim Yargıtay da bir kararında ${ }^{104}$ ceza yargılaması ile satılanın alıcının elinden alınmasında zapt hükümlerini haklı olarak uygulamıştır. Ceza ve özel hukuk mahkemeleri arasında ihbar ve müdahalenin etkisi ilişkisi bulunamayacağından ceza mahkemesinin kararı TBK m. 74 anlamında özel hukuk mahkemesince dikkate alınmak gerekecektir.

\section{ZAPTTAN SORUMLULUKTA ZAMANAŞIMI}

Bir alacak zamanaşımına uğradığında, alacaklı hakkını borçluya karşı ileri sürdüğü takdirde borçlu, zamanaşımı def'ini kullanarak, alacaklının alacak hakkına bağlı ${ }^{105}$ talep hakkının kullanmasının önüne geçebiliri ${ }^{106}$.

100 Gümüş, s. 56; Ayrıca: Yıldırım, M. Fadıl: "Satıcının Zapta Karş1 Tekeffül Sorumluluğu Bakımından 6098 sayılı Türk Borçlar Kanunu'nun 216. Maddesi Nasıl Okunmalıdır?", Gazi Üniversitesi Hukuk Fakültesi Dergisi, C. 17 S. 1-2 (2013), s. 1157 vd.

101 Tandoğan, s. 154; Bu konuda: Yavuz, s. 111; Acar, s. 111 vd.; Aydoğdu/Kahveci, s. 123; Zevkliler/Gökyayla, s. 143-144; Önceki düzenlemenin yerinde olduğu ve eşyay1 tartışmasız çekişmesiz şekilde üçüncü kişiye verenin genel hükümlere de gidemeyeceği görüşünde bkz. Hatemi/Serozan/Arpacı, s. 82.

102 Tandoğan, s. 155; Tunçomağ, s. 212; Yavuz, s. 114. Nitekim bazı kararlarında Yargıtay bu yönde de karar vermiştir: Yarg. 13. HD., 29.1.1986, 7858/427 (Kazanc1); Yarg. 13. HD., 21.11.1988, 3920/5535 (Kazanc1).

103 Üçüncü kişinin üstün hakkının kanıtlanmasının zorunlu olduğu, sadece şikâyetin yeterli olmadığı hususunda: Yarg. 13. HD., 29.1.1986, 7858/427 (Kazanc1); Ayrıca: Yarg. 13. HD., 13.3.2013, 56/6242 (Kazanc1) .

104 Yarg. 11. HD., 25.5.1989, 351/3111 (Kazanc1).

105 Talebin, alacak hakkından ayrı ancak ona bağlı olduğu hususunda: Oğuzman/Öz, C. I, N. 50; Oğuzman, M. Kemal/Barlas, Nami: Medeni Hukuk, İstanbul, 2018, N. 975; Dural, Mustafa/Sarı, Suat: Temel Kavramlar ve Medeni Kanunun Başlangıç Hükümleri, İstanbul, 2015, s. 258; Von Tuhr, Andreas/Peter, Hans: Allgemeiner Teil des Schweizerischen Obligationenrechts Band I, Zürich, 1984, §2 VI, s. 15 vd.

106 Feyzioğlu, Feyzi N., Borçlar Hukuku Genel Hükümler, C. II, İstanbul, 1977, s. 602-603; Nomer, Haluk N.: Borçlar Hukuku Genel Hükümler, İstanbul, 2020, N. 211-211.13; Oğuzman/Öz, C. I, N. 1959; İnan, Ali Naim/Yücel Özge: Borçlar Hukuku Genel Hükümler, Ankara, 2014, s. 647; Eren, N. 4051. 
Zamanaşımın dolmasıyla borçlu lehine def'i hakkı doğar. Alacak hakkı varlığını korurken, alacağa bağlı talep hakkı, def'inin borçlu tarafından kullanılmasıyla baskılanır ${ }^{107}$. Dolayısıyla, satıcının zapttan sorumluluğunu sona erdirmemekle birlikte alıcı tarafindan ileri sürülmesini engelleyen bir sebep olarak zamanaşımının da bu çalışma kapsamında değerlendirilmesi icap etmektedir.

Zapttan doğan sorumluluğa ilişkin olarak, ayıba ilişkin sorumlulukta söz konusu olduğu gibi, yasada hakka zamansal sinırlama getiren herhangi bir özel hüküm sevk edilmemiştir. Zapttan sorumluluk satıcı için bir borç olduğu için zamanaşımına tabi olur ve TBK m. 146 uyarınca bu sorumluluğa ilişkin olarak on yıllık genel zamanaşımı süresi uygulama alanı bulur ${ }^{108}$.

Zamanaşımı süresinin ise hangi andan itibaren işlemeye başlayacağına ilişkin öğretide görüş birliği yoktur. Bir görüşe göre bu süre, sözleşmenin kurulması bir diğer görüşe göre ise teslim anı, bir diğerine göre ise zapt anından itibaren başlamalıdır ${ }^{109}$. Burada hareket noktası, fikrimizce, zapttan sorumluluğun satıcının satılanı teslim ve mülkiyetini devretme borçlarının yansıması olmasıdır. Başka bir deyişle bu borçların varlığı zapttan sorumluluğun varlık nedenini oluşturur. Dolayısı ile satıcının zapttan doğan sorumluluğuna, satılanı teslim ve devir borcunun muacceliyet kazanmasıyla zamanaşımı işlemeye başlamalıdır ${ }^{110}$. Zapttan sorumluluğa, zaptın gerçekleşmesi anından itibaren zamanaşımının işleyeceği kabul edilirse, satıcının bu borçtan sorumluluğunun zapt gerçekleşmedikçe asla zamanaşımına uğramayacağı sonucu ortaya çıkar. Böylece bu görüşe göre, satılanı hiç teslim

107 Tercier/Pichonnaz/Develioğlu, N. 1545-1546; Erdem, Mehmet: Özel Hukukta Zamanaşımı, İstanbul, 2010, s. 349 vd.

108 CR-Venturi/Zen-Ruffinen, Art. 192 CO, N. 3; BSK-Honsell, Art. 192 OR, N. 11; Yarg. 13. HD., 24.11.1986, 4482/5734 (Kazanc1); Yarg. 13. HD., 20.3.1995, 2191/2694 (Kazanc1); Eren, N. 255; Tunçomağ, s. 226; Doğu, s. 525; CHK-Hrubesch-Millauer, Art. 192 OR, N. 5; OFK-Kostkiewicz, Art. 192 OR, N. 11. İsviçre'de İBK m. 196a hükmüyle, satış sözleşmesine kültür varlığının konu olması halinde zaptın gerçekleşmesi olasılığına ilişkin olarak özel bir zamanaşımı rejimi öngörülmüştür. Buna göre, zapttan sorumluluktan doğan dava hakkına ilişkin zamanaşımı, alıcının bu durumu fark etmesinden itibaren bir yılın ve her halükarda sözleşmenin kurulmasından itibaren otuz yılın dolmasıyla gerçekleşecektir.

109 Bu hususta bkz. Gümüş, s. 57; BSK-Honsell, Art. 192 OR, N. 11; Yarg. 13. HD., 9.2.2016, 47465/3694 (Lexpera). Zapt davasının kesinleşmesinden itibaren işleyeceği fikrinde: Eren, N. 255; Aydoğdu/Kahveci, s. 129; Yarg. 1. HD., 16.12.2009, 11411/ 13279 (Kazanc1); Yarg. 1. HD., 21.9.2011, 6761/9035 (Kazanc1); Fiili zapt anından itibaren işlemesi gerektiği ve bu andan önce zapta ilişkin talep edilebilir bir hak olmadığı gerekçesiyle: BK-Giger, Art. 192 OR, N. 83.

110 Sözleşmenin kurulması anı şeklinde: Gümüş, s. 57; BSK-Honsell, Art. 192 OR, N. 11. 
etmeyen satıcı, alıcının ifa istemine karşılık zamanaşımı def'ini ileri sürebilirken, teslimden sonra on yılı aşkın bir süre sonra gerçekleşen zapt halinde savunma imkânından mahrum kalması gibi kabul edilemez bir sonuç doğar. Zira bu durumda istisnai ve alıc lehine bir sorumluluk rejimi olan zapttan sorumluluğun tabi olduğu zamanaşımı, genel sorumluluğun tabi olduğu zamanaşımından çok daha uzun olur. Hiç teslim etmeyen satıcı ile teslim etmekle birlikte mülkiyeti devredemeyen satıcı arasında böyle bir ayrım yapmayı gerektirecek menfaat veya hukuki durum farklılığ yoktur.

Zapttan sorumluluk hükümleri kural olarak emredici olmadığından zamanaşımı süreleri kısaltılabilir veya uzatılabilir ${ }^{111}$. Sürenin kısaltılması sorumsuzluk anlaşması niteliğinde olacağından ${ }^{112}$ TBK m. 214/III hükmüne tabi olur.

\section{SONUÇ}

Satış sözleşmesinde zapttan sorumluluk, Roma hukukunun bir kalıntısını oluşturmakta olup alıcının elinde satılanın satış sözleşmesinin kurulduğu anda mevcut bir üstün hak nedeniyle elinden alınmasında kaynaklanan sorumluluğu ifade eder. $\mathrm{Bu}$ sorumluluğun satılanın mülkiyetini ve zilyetliğini devir borcunun bir yansıması olduğu dikkate alınırsa, zapttan sorumluluğun, satılanın mülkiyetini devri borcuyla aynı zamanaşımı süresine tabi olması gerektiği kabul edilmelidir.

Zapttan sorumluluk, sözleşme tam zaptın gerçekleşmesi sözleşmeden dönülmesi veya sözleşmenin iptal edilmesi sonucu sona ermedikçe, irade bozukluğu ve borçlu temerrüdü hükümleriyle yarışabilir. Bu itibarla zapttan sorumluluğun söz konusu olabilmesi olarak öncelikle hüküm ifade eden bir satış sözleşmesi bulunmalıdır. Sözleşmenin, özel mülkiyete tabi olmayacak veya müsaderesine hükmedilmiş bir eşyayı konu edinmesi gibi TBK m. 27'ye aykırılık teşkil eden hallerde bu nedenle zapttan sorumluluk söz konusu olmamalıdır. Öte yandan, üçüncü kişinin hakkına dayanmayan, hukuk düzeninin genel sinırlamalarından kaynaklanan nedenlerle satılandan yararlanılamaması zapt olarak nitelendirilemez. Zapttan sorumluluğu ortadan kaldıran bir sorumsuzluk anlaşması yapılabilir. Bu anlaşma satıcının zapt tehlikesini gizlediği hallerde hükümsüzdür. Bununla birlikte sorumsuzluk

\footnotetext{
111 ZK-Schönle/Higi, Art. 192 OR, N. 67; On yıldan fazla zamanaşımı süresi tanınıp tanınamayacağı ayıptan doğan sorumlulukta kabul edilecek görüşe koşut olacaktır. Bu tartışma hakkında bkz. Gümüş, s. 116.

112 Başalp, s. 10; Akman, s. 23-25.
} 
anlaşmasının genel hükümlerden doğan sorumluluğunu da etkilediği sonucuna ulaşıllyorsa bu anlaşma TBK m. 115'e tabi olacaktır.

Güven ilkesine koşut biçimde, alıcı zapt tehlikesinden haberdar ise, satıcı özel olarak taahhüt etmedikçe zapttan sorumlu olmaz. Alıcı zapt tehlikesinin haberdar değilse ancak haberdar olması gerekiyorsa, alıcının kast düzeyine varmayan ihmalinden kaynaklanan bilgisizliği halinde de satıcının zapt sorumluluğuna gidebilmesine olanak tanınmalıdır.

Zapttan sorumluluğun gerçekleşebilmesi için satılanın teslim edilmiş olması da gereklidir. Tapu siciline kayıtlı taşınmazlarda ise alıcı lehine tescilin yapılmış olması lazım gelir. Ayrıca, satılan alıcının elinden, üstün hakkın ileri sürülmesi ve bu hakkın iradi veya yargısal yolla tanınması sonucunda çıkmadığı takdirde zapttan sorumluluk gerçekleşmez, alıcı genel hükümlere başvurabilir.

Zapta olanak veren üstün haklar, alıcının ileri sürülen hakka karş1 savunma olanağının bulunup bulunmamasına göre belirlenmek gerekir. Buna göre, mutlak haklar, şerhten veya kanundan doğan eşyaya bağlı yükümlülükler, satılanın haczedilmiş olması, satılanın kiralanmış olması (TBK m. 310) zapttan sorumluluğa yol açabilir. Ancak satım konusu üzerinde, devri amaçlanan hak ile özdeş olmayan bir başka mutlak hak ileri sürülüyorsa bu durumda kanımızca zapt söz konusu olmaz, hukuki ayıp hükümleri uygulanmak gerekir. 


\section{KAYNAKÇA}

Acar, Özlem: "Satıcının Zapttan Sorumluluğu", İstanbul Kültür Üniversitesi Hukuk Fakültesi Dergisi, C. 13, S. 1 (2014).

Akman, Galip Sermet: Sorumsuzluk Anlaşması, İstanbul, 1976.

Akman, Galip Sermet: Taşkın İnşaat, İstanbul, 1982.

Antalya, O. Gökhan/Sağlam, İpek: Miras Hukuku, İstanbul, 2015.

Aral, Fahrettin/Ayrancı, Hasan: Borçlar Hukuku Özel Borç İlişkileri, Ankara, 2018.

Atamer, Yeşim: "Taşınır Satımı Sözleşmesi”, Türk Borçlar Kanunu Sempozyumu, İstanbul, 2012.

Atlı, Banu: "Taşkın Yapıya Katlanma Yükümlülüğünün Oluşma Koşulları”, Dokuz Eylül Üniversitesi Hukuk Fakültesi Dergisi, C. 19 (Özel Sayı: Prof. Dr. Şeref Ertaş’a Armağan-2017).

Aydoğdu, Murat/Kahveci, Nalan: Türk Borçlar Hukuku Özel Borç İlişkileri, Ankara, 2019.

Başalp, Nilgün: Sorumsuzluk Anlaşmaları, İstanbul, 2011.

Baytaz, Abdullah Batuhan: Türk Ceza Hukukunda Müsadere (TCK m. 5554), Yüksek Lisans Tezi (Marmara Üniversitesi Sosyal Bilimler Enstitüsü), İstanbul, 2009.

Bucher, Eugen: Obligationenrecht, Besonderer Teil, Zürih 1988.

Cavin, Pierre: Traité du Droit Privé Suisse - VII-1 - La Vente L'Echange La Donation, Friburg, 1978.

Çabri, Sezer: "Taşınmaz Satışında Satıcının Zapttan Sorumluluğu", Marmara Üniversitesi Hukuk Fakültesi Hukuk Araştırmaları Dergisi, C. 22, S. 3 (2016-Prof. Dr. Cevdet Yavuz'a Armağan).

Doğan, Murat: Tapu Sicilinde Tasarruf Yetkisi Kısıtlaması Şerhi, Ankara, 2004.

Doğu, H. Mert: "Ardı Ardına Teslimli Satış Sözleşmesinde Satıcının Ayıptan ve Zapttan Sorumluluğu”, Selçuk Üniversitesi Hukuk Fakültesi Dergisi, C. 26, S. 2 (2018).

Dural, Mustafa/Sarı, Suat: Temel Kavramlar ve Medeni Kanunun Başlangıç Hükümleri, İstanbul, 2015.

Eggen, Mirjam: “eBook - myBook oder yourBook?”, recht 2017.

Engel, Pierre: Contrats de droit suisse, Bern, 2000. 
Engin, Baki İlkay: Alacağın Temlik Edenin Garanti Sorumluluğu, Ankara, 2002.

Ercoşkun Şenol, H. Kübra: "Hem Haksız Hem de Taşkın Yapı Niteliğindeki Yapılar”, Türkiye Adalet Akademisi Dergisi Y1l: 11, S. 38 (Nisan 2019).

Ercoşkun Şenol, H. Kübra: "Türk Borçlar Hukukunda Hilenin Münferit Uygulama Alanları”, Gazi Üniversitesi Hukuk Fakültesi Dergisi, C. 17, S. 4 (Ekim 2013) (Hile).

Erdem, Mehmet: Özel Hukukta Zamanaşımı, İstanbul, 2010.

Eren, Fikret: Borçlar Hukuku Genel Hükümler, Ankara, 2019.

Eren, Fikret: Borçlar Hukuku Özel Hükümler, Ankara, 2019.

Erten, Ali: Türk Sorumluluk Hukukunda Sorumsuzluk Şartları, Ankara, 1977.

Feyzioğlu, Feyzi N.: Borçlar Hukuku Genel Hükümler, C. II, İstanbul, 1977.

Feyzioğlu, Feyzi N.: Borçlar Hukuku İkinci Kısım Akdin Muhtelif Nevileri, C. I, İstanbul, 1980.

Giger, Hans: Berner Kommentar Das Obligationen Recht 2. Abteilgung I. Teil Band 1. Abschnitt, Bern, 1980.

Gümüş, Mustafa Alper: Borçlar Hukuku Özel Hükümler, C. I, İstanbul, 2013.

Günel, M. Cahit: Taşınmaz Rehninin Kapsamı Çerçevesinde Eklentinin Hukuki Durumu, İstanbul, 2013.

Hatemi, Hüseyin/Serozan, Rona/Arpacı, Abdülkadir: Borçlar Hukuku Özel Bölüm, İstanbul, 1992.

Honsell, Heinrich: Basler Kommentar - Obligationenrecht I Art. 1-529 OR, 4. Bask1, Basel, 2007.

Hrubesch-Millauer, Stephanie: CHK-Handkommentar zum Schweizer Privatrecht- Vertragsverhältnisse Teil 1: Innominatkontrakte, Kauf, Tausch, Schenkung, Miete, Leihe Art. 184 - 318 OR, Art. 192 OR, Zürih-Basel-Cenevre, 2016.

Huguenin, Claire: Obligationenrecht Allgemeiner und Besonderer Teil, Zürih, 2014.

İnan, Ali Naim/Yücel, Özge: Borçlar Hukuku Genel Hükümler, Ankara, 2014. 
Kapancı, Kadir Berk: Satış Hukukunda Ayıptan Doğan Sorumluluk ve Sözleşmesel Garanti Taahhütleri, İstanbul, 2012.

Kılıçoğlu, Ahmet M.: Borçlar Hukuku Özel Hükümler, Ankara, 2019.

Kızılay, Aygül: "Türk Borçlar Kanunu ile Milletlerarası Mal Satımına İlişkin Sözleşmeler Hakkında Birleşmiş Milletler Antlaşması (CISG) Hükümleri Çerçevesinde Satış Sözleşmesinde Ayıptan Sorumlulukta Alıcının Seçtiği Hakkın Sonradan Değiştirilebilirliği Sorunu", Hacettepe HFD 7(2) 2017.

Koller, Alfred: Schweizerisches Obligationenrecht, Besonderer Teil, Band I Die einzelnen Vertragsverhältnisse Art. 184-318 OR, Bern, 2012.

Kostkiewicz, Jolanta Kren: OFK Orell Füssli Kommentar (Navigator.ch)OR Kommentar Schweizerisches Obligationenrecht, Zürih, 2016.

Kuonen, Nicolas: "Les relations entre les intervenants dans la construction", Journees suisse du droit de la construction 2011, 2010, Institut für Schweizerisches und Internationales Baurecht.

Kuru, Baki: İcra ve İflas Hukuku El Kitabı, Ankara, 2013.

Nomer, Haluk N./Engin, B. İlkay: Türk Borçlar Kanunu Şerhi Özel Borç İlişkileri Cilt I: Satış Sözleşmesi, Ankara, 2018.

Nomer, Haluk N.: Beklenen Haklar Üzerindeki Tasarrufların Hukuki Sonuçları, İstanbul, 2002.

Nomer, Haluk N.: Borçlar Hukuku Genel Hükümler, İstanbul, 2020.

Oğuzman, M. Kemal/Barlas, Nami: Medeni Hukuk, İstanbul, 2018.

Oğuzman, M. Kemal/Öz, Turgut: Borçlar Hukuku Genel Hükümler, C. I, İstanbul, 2018.

Oğuzman, M. Kemal/Seliçi, Özer/Oktay-Özdemir, Saibe: Eşya Hukuku, İstanbul, 2018.

Öz, Turgut: Yeni Borçlar Kanununun Getirdiği Başlıca Değişiklikler ve Yenilikler, İstanbul, 2011.

Özen, Burak: "Kira Konusunun Devri”, Bahçeşehir Üniversitesi Hukuk Fakültesi Dergisi, C.9, S. 103-104 (2013).

Özmen, E. Saba: "Türk Hukukunda Hacizlerin Şerhle Kazandığı Hukuki Nitelik ve Buna Bağlı Hukuki Sonuçların İrdelenmesi”, Ankara Barosu Dergisi, S. 2, 1991.

Pekcanıtez, Hakan/Atalay, Oğuz/Sungurtekin-Özkan, Meral/Özekes, Muhammet: İcra ve İflâs Hukuku, Ankara, 2012. 
Pekmez, Cüneyt: "Satış Sözleşmesinde Zaptın Hukuki Sonuçları", Türkiye Adalet Akademisi Dergisi, Y1l: 6, S. 20 (Ocak 2015).

Postacıoğlu, İlhan/Altay, Sümer: İcra Hukuku Esasları, İstanbul, 2010.

Rüegg, Eric: "§ 5 Die Haftung des Grundstückverkäufers/I.-IV.", Der Grundstückkauf, Ed. Alfred Koller, Bern, 2017.

Schmid, Jörg: "Die Gewährleistung beim Grundstückkauf Ausgewählte Fragen unter Berücksichtigung von Altlasten", Schweizerische Zeitschrift für Beurkundungs- und Grundbuchrecht, S. 81, 2000.

Schönle, Herbert/Higi, Peter: Zürcher Kommentar Band/Nr. V/2a Kommentar zum Schweizerischen Zivilgesetzbuch, Obligationenrecht, Kommentar zur 1. und 2. Abteilung (Art. 1-529 OR) Kauf und Schenkung, Zweite Lieferung, Art. 192-204 OR, Zürih, 2005.

Schumacher, Rainer/Rüegg, Erich: "§ 5 Die Haftung des Grundstückverkäufers / III.-IV.”, Der Grundstückkauf, 2. Bask1, Bern, 2001, Editör: Alfred Koller.

Serozan, Rona: "Komşunun Arsasına Taşan Yapı", İstanbul Üniversitesi Hukuk Fakültesi Mecmuas1, C. 42, S. 1-4 (1976).

Sirmen, Lale: Türk Özel Hukukunda Şart, Ankara, 1992.

Şahiniz, Salih: Tacirler Arası Ticari Satımlarda Satıcının Ayıplı İfadan Sorumluluğu, Ankara, 2008.

Tandoğan, Haluk: Borçlar Hukuku Özel Borç İlişkileri, Cilt 1/I ve 1/2, İstanbul, 2008.

Tercier, Pierre/Pichonnaz, Pascal/Develioğlu, H. Murat: Borçlar Hukuku Genel Hükümler, İstanbul, 2016.

Tercier, Pierre/Venturi, Silvio: Les contrats speciaux, Zürih, 1995.

Tunçomağ, Kenan: Türk Borçlar Hukuku, 2. Cilt Özel Borç İlişkileri, İstanbul, 1977.

Türker, Erhan: Türk ve İngiliz Hukukunda Satıcının Zapta Karşı Teminat Borcu, Eskişehir, 1974.

Venturi, Silvio/Zen-Ruffinen, Marie-Noëlle: Commentaire Romand-Code des Obligations Art. 1-529, Basel, 2012.

Vionnet, Guillaume: L'exercice des droits formateurs, Zürih-Basel-Cenevre, 2008.

Von Tuhr, Andreas/Peter, Hans: Allgemeiner Teil des Schweizerischen Obligationenrechts Band I, Zürich, 1984. 
Yavuz, Cevdet: Satıcının Satılanın Ayıplarından Sorumluluğu, İstanbul, 1989.

Yavuz, Cevdet: Türk Borçlar Hukuku Özel Hükümler, İstanbul, 2014 (Hazırlayanlar: Yavuz, Cevdet/Acar, Faruk/Özen, Burak).

Yücedăg, Nafiye: Sözleşmeye Aykırı Mal Tesliminde Yenisiyle Değiştirme Hakkı -TBK ve CISG Uyarınca, İstanbul, 2018.

Yüksel, Halil İbrahim: Roma Hukukunda satış sözleşmesi (Emptiovenditio), IÜSBE Yüksek Lisans Tezi, İstanbul, 2015.

Zevkliler, Aydın/Gökyayla, K. Emre: Borçlar Hukuku Özel Borç İlişkileri, Ankara, 2018.

Zimmermann, Reinhard: The Law of Obligations - Roman Foundations of the Civilian Tradition, Cape, 1992. 


\section{KISALTMALAR}
ATF
: Arrêts du Tribunal Federal
b.
: Bent
Bkz.
: Bakınız
C.
: Cilt
dn.
: Dipnotu
HD.
: Hukuk Dairesi
HGK.
: Hukuk Genel Kurulu
İBK
: İsviçre Borçlar Kanunu
IIIK
: İcra ve İflas Kanunu
JdT
: Journal des Tribunaux
Karş.
: Karşılaştırınız
Kazancı
: Kazancı Çevrimiçi İçtihat Bilgi Bankası
Lexpera
: Lexpera Çevrimiçi Hukuk Bilgi Bankası
m.
: Madde
N.
: Kenar/Paragraf Numaras1
s.
: Sayfa
S.
: Say1
TBK
: Türk Borçlar Kanunu
TCK
: Türk Ceza Kanunu
TMK
: Türk Medeni Kanunu
TTK
: Türk Ticaret Kanunu
Yarg.
: Yargitay 